Article

\title{
Transcatheter Aortic Valve Replacement with Self-Expandable ACURATE neo as Compared to Balloon-Expandable SAPIEN 3 in Patients with Severe Aortic Stenosis: Meta-Analysis of Randomized and Propensity-Matched Studies
}

\author{
Mirosław Gozdek 1,2, Kamil Zieliński ${ }^{2,3}$, Michał Pasierski ${ }^{2,4}$, Matteo Matteucci ${ }^{5,6}$ (D),
} Dario Fina ${ }^{5,7}$, Federica Jiritano ${ }^{5,8}$, Paolo Meani ${ }^{5,9}$, Giuseppe Maria Raffa ${ }^{10}$, Pietro Giorgio Malvindi ${ }^{11}$ (D), Michele Pilato ${ }^{10}$, Domenico Paparella ${ }^{12,13}$, Artur Słomka ${ }^{2,14}$ (D), Jacek Kubica ${ }^{1}$, Dariusz Jagielak ${ }^{15}$, Roberto Lorusso ${ }^{5}$, Piotr Suwalski ${ }^{4}$ and Mariusz Kowalewski ${ }^{2,4,5, *}$ on behalf of Thoracic Research Centre

1 Department of Cardiology and Internal Medicine, Nicolaus Copernicus University, Collegium Medicum, 85067 Bydgoszcz, Poland; gozdekm@wp.pl (M.G.); kubicajw@gmail.com (J.K.)

2 Thoracic Research Centre, Nicolaus Copernicus University, Collegium Medicum in Bydgoszcz, Innovative Medical Forum, 85067 Bydgoszcz, Poland; kamilziel@gmail.com (K.Z.); michalpasierski@gmail.com (M.P.); artur.slomka@cm.umk.pl (A.S.)

3 Department of Cardiology, Warsaw Medical University, 02091 Warsaw, Poland

4 Clinical Department of Cardiac Surgery, Central Clinical Hospital of the Ministry of Interior and Administration, Centre of Postgraduate Medical Education, 02607 Warsa, Poland; suwalski.piotr@gmail.com

5 Department of Cardio-Thoracic Surgery, Heart and Vascular Centre, Maastricht University Medical Centre, 6229 HX Maastricht, The Netherlands; teo.matte@libero.it (M.M.); dario.fina88@gmail.com (D.F.); fede.j@hotmail.it (F.J.); paolo.meani@ospedaleniguarda.it (P.M.); roberto.lorussobs@gmail.com (R.L.) Department of Cardiac Surgery, Circolo Hospital, University of Insubria, 21100 Varese, Italy Department of Cardiology, IRCCS Policlinico San Donato, University of Milan, 20097 Milan, Italy Department of Cardiac Surgery, University Magna Graecia of Catanzaro, 88100 Catanzaro, Italy

9 Department of Intensive Care Unit, Maastricht University Medical Centre (MUMC+), 6229 HX Maastricht, The Netherlands

10 Department for the Treatment and Study of Cardiothoracic Diseases and Cardiothoracic Transplantation, IRCCS-ISMETT (Instituto Mediterraneo per i Trapianti e Terapie ad alta specializzazione), 90127 Palermo, Italy; giuseppe.raffa78@gmail.com (G.M.R.); mpilato@ISMETT.edu (M.P.)

11 Wessex Cardiothoracic Centre, University Hospital Southampton, Southampton SO16 6YD, UK; pg.malvindi@hotmail.com

12 GVM Care \& Research, Department of Cardiovascular Surgery, Santa Maria Hospital, 70124 Bari, Italy; domenico.paparella@uniba.it

13 Department of Emergency and Organ Transplant, University of Bari Aldo Moro, 70121 Bari, Italy

14 Chair and Department of Pathophysiology, Nicolaus Copernicus University, Collegium Medicum, 85067 Bydgoszcz, Poland

15 Department of Cardiac Surgery, Gdańsk Medical University, 80210 Gdańsk, Poland; kardchir@gumed.edu.pl

* Correspondence: kowalewskimariusz@gazeta.pl; Tel.: +0048-502-269-240

Received: 30 December 2019; Accepted: 30 January 2020; Published: 1 February 2020

\begin{abstract}
Frequent occurrence of paravalvular leak (PVL) after transcatheter aortic valve replacement (TAVR) was the main concern with earlier-generation devices. Current meta-analysis compared outcomes of TAVR with next-generation devices: ACURATE neo and SAPIEN 3. In random-effects meta-analysis, the pooled incidence rates of procedural, clinical and functional outcomes according to VARC-2 definitions were assessed. One randomized controlled trial and five observational studies including 2818 patients (ACURATE neo $n=1256$ vs. SAPIEN $3 n=1562$ ) met inclusion criteria.
\end{abstract} ACURATE neo was associated with a 3.7-fold increase of moderate-to-severe PVL (RR (risk ratio): 
3.70 (2.04-6.70); $P<0.0001)$, which was indirectly related to higher observed 30-day mortality with ACURATE valve (RR: $1.77(1.03-3.04) ; P=0.04)$. Major vascular complications, acute kidney injury, periprocedural myocardial infarction, stroke and serious bleeding events were similar between devices. ACURATE neo demonstrated lower transvalvular pressure gradients both at discharge $(P<0.00001)$ and at 30 days $(P<0.00001)$, along with lower risk of patient-prosthesis mismatch (RR: $0.29(0.10-0.87)$; $P=0.03)$ and pacemaker implantation (RR: $0.64(0.50-0.81) ; P=0.0002)$, but no differences were observed regarding composite endpoints early safety and device success. In conclusion, ACURATE neo, as compared with SAPIEN 3, was associated with higher rates of moderate-to-severe PVL, which were indirectly linked with increased observed 30-day all-cause mortality.

Keywords: meta-analysis; ACURATE neo; SAPIEN 3; transcatheter aortic valve replacement

\section{Introduction}

Since first its mention by Cribier in 2002 [1], transcatheter aortic valve replacement (TAVR) has been complementary method to surgical aortic valve replacement (SAVR) in inoperable or high-risk patients with severe symptomatic aortic stenosis. Similar [2] or even lower [3] one-year mortality rate of TAVR, as compared to SAVR, was shown in selected groups of patients. Hence, TAVR is now considered to be an alternative treatment option and is recommended not only in inoperable, high or increased risk surgical patients [2-5] but also in intermediate and lower risk individuals [6-10]. Commercially available earlier-generation transcatheter valves, despite providing good clinical outcomes, were not free from shortcomings; indeed, high rates of conduction abnormalities, permanent pacemaker implantation (PPI) or vascular complications remained important issues to be addressed. More importantly, though, higher incidence of paravalvular leak (PVL), in turn associated with increased late mortality and higher rate of other adverse clinical incidents, as compared to SAVR [11-13], often outweigh the benefits of transcatheter approach.

To minimize these shortcomings, technological innovations were developed in next-generation valves including the following: balloon-expandable SAPIEN 3 (Edwards Lifesciences, Irvine, CA, USA) and self-expandable ACURATE neo (Boston Scientific Corporation, Marlborough, MA, USA). Since direct comparisons of these two devices are few and one recent randomized controlled trial (RCT) [14] did not demonstrate non-inferiority of the ACURATE neo device as compared to SAPIEN 3 as opposed to previous observational studies [15-21] that, however, pointed to comparable or superior results with ACURATE, the debate is ongoing.

The objective of the present investigation was to evaluate and compare short-term results of TAVR with ACURATE neo and SAPIEN 3 in patients presenting with symptomatic severe native aortic valve stenosis.

\section{Experimental Section}

\subsection{Data Sources and Search Strategy}

The systematic review and meta-analysis were performed in accordance to MOOSE statement and PRISMA guidelines [22,23]. The MOOSE checklist is available as Table A1. We searched PubMed, ClinicalKey, the Web of Science and Google Scholar all until October 2019. Search terms were as follows: "ACURATE neo" (or "ACCURATE neo"), "Symetic ACURATE", "Boston ACURATE" and/or "SAPIEN 3", "SAPIEN III" and "transcatheter valve" or "aortic". The literature was limited to peer-reviewed articles published in English. References of original articles were reviewed manually and cross-checked. 


\subsection{Selection Criteria and Quality Assessment}

Studies were included if having met all of the following criteria: (1) human study; (2) study or study arms comparing directly strategy of transcatheter aortic valve replacement with ACURATE neo and SAPIEN 3; (3) RCT or propensity score matched observational study. Studies were excluded if they fell into the following categories: (1) in-vitro study; (2) single arm; (3) adjustment not PS or methods not reported; (4) outcomes of interest not reported; and (5) sub-studies or overlapping populations. No restrictions regarding number of patients included or characteristic of the population were imposed. Two reviewers (M.G. and K.Z.) selected the studies for the inclusion, extracted studies and patients' characteristics of interest and relevant outcomes. Two authors (M.G. and K.Z.) independently assessed the trials' eligibility and risk of bias. Any divergences were resolved by consensus.

Quality of RCTs was appraised by using the components recommended by the Cochrane Collaboration [24]; observational studies were, instead, appraised with ROBINS-I (Risk of Bias in Nonrandomised Studies-of Interventions), a tool used for assessment of the bias (the selection of the study groups; the comparability of the groups; and the ascertainment of either the exposure or outcome of interest) in cohort studies included in a systematic review and/or meta-analysis [25].

\subsection{Endpoints Selection}

Endpoints were established according to the Valve Academic Research Consortium-2 (VARC-2) definitions [26]. Procedural outcomes of interest were predilatation and postdilatation, procedural times and contrast volume. Clinical endpoints assessed included the following: PPI, major vascular complications (MVC), serious bleeding (life-threatening and/or major), acute kidney injury (AKI), stroke, myocardial infarction and 30-day mortality. Functional outcomes were as follows: mean transvalvular gradients, prosthesis-patient mismatch (PPM), and mild and moderate-to-severe paravalvular leak (PVL). Composite endpoints were as per VARC-2: device success (defined as absence of procedural death, correct position of 1 valve in the proper location, mean gradient $<20 \mathrm{~mm} \mathrm{Hg}$ or peak velocity $<3 \mathrm{~m} / \mathrm{s}$, absence of moderate-to-severe PVL and absence of PPM) and early safety (composite of all-cause death, any stroke, life-threatening or disabling bleeding, major vascular complications, coronary artery obstruction requiring intervention, acute kidney injury (stage 2 or higher), rehospitalization for valve-related symptoms or congestive heart failure, valve-related dysfunction requiring repeat procedure, and valve-related dysfunction determined by echocardiography (mean aortic valve gradient $\geq 20 \mathrm{~mm} \mathrm{Hg}$ and either effective orifice area $\leq 0.9-1.1 \mathrm{~cm}^{2}$ (depending on body surface area) or Doppler velocity index $<0.35$; or moderate or severe prosthetic PVL).

\subsection{Statistical Analysis}

Data were analyzed according to intention-to-treat principle, wherever applicable. Risks ratios (RR) and 95\% confidence intervals (95\% CI) served as primary index statistics for dichotomous outcomes. For continuous outcomes, mean difference (MD) and corresponding 95\% CI were calculated by using a random effects model. To overcome the low statistical power of Cochran $Q$ test, the statistical inconsistency test $I^{2}=[(\mathrm{Qdf}) / \mathrm{Q}] \times 100 \%$, where $\mathrm{Q}$ is the chi-square statistic and $\mathrm{df}$ is its degrees of freedom, was used to assess heterogeneity [27]. It examines the percentage of inter-study variation, with values ranging from $0 \%$ to $100 \%$. An $I^{2}$ value of $25 \%$ indicates low heterogeneity, $50 \%$ are suggestive of moderate heterogeneity and $70 \%$ of high heterogeneity. Because of high degree of heterogeneity anticipated among predominantly nonrandomized trials, an inverse variance (DerSimonian-Laird) random-effects model was applied as a more conservative approach for observational data accounting for between- and within-study variability. Whenever a single study reported median values and interquartile ranges instead of mean and standard deviation (SD), the latter were approximated as described by Wan and colleagues [28]. In case there were " 0 events" reported in both arms, calculations were repeated, as a sensitivity analysis, using risk difference (RD) and respective $95 \%$ CI. Additionally, we performed a set of meta-regression analyses to address potential relationships between 30-day 
all-cause mortality and other endpoints and baseline characteristics assessed. For the analyses of clinical endpoints, RCTs and PS-matched studies were analyzed separately. Review Manager 5.3 (The Nordic Cochrane Centre, Copenhagen, Denmark) was used for statistical computations. $P$-values $\leq 0.05$ were considered statistically significant and reported as two-sided, without adjustment for multiple comparisons.

\section{Results}

\subsection{Study Selection and Bias}

Study selection process and reasons for exclusion of some studies are described in Figure 1.

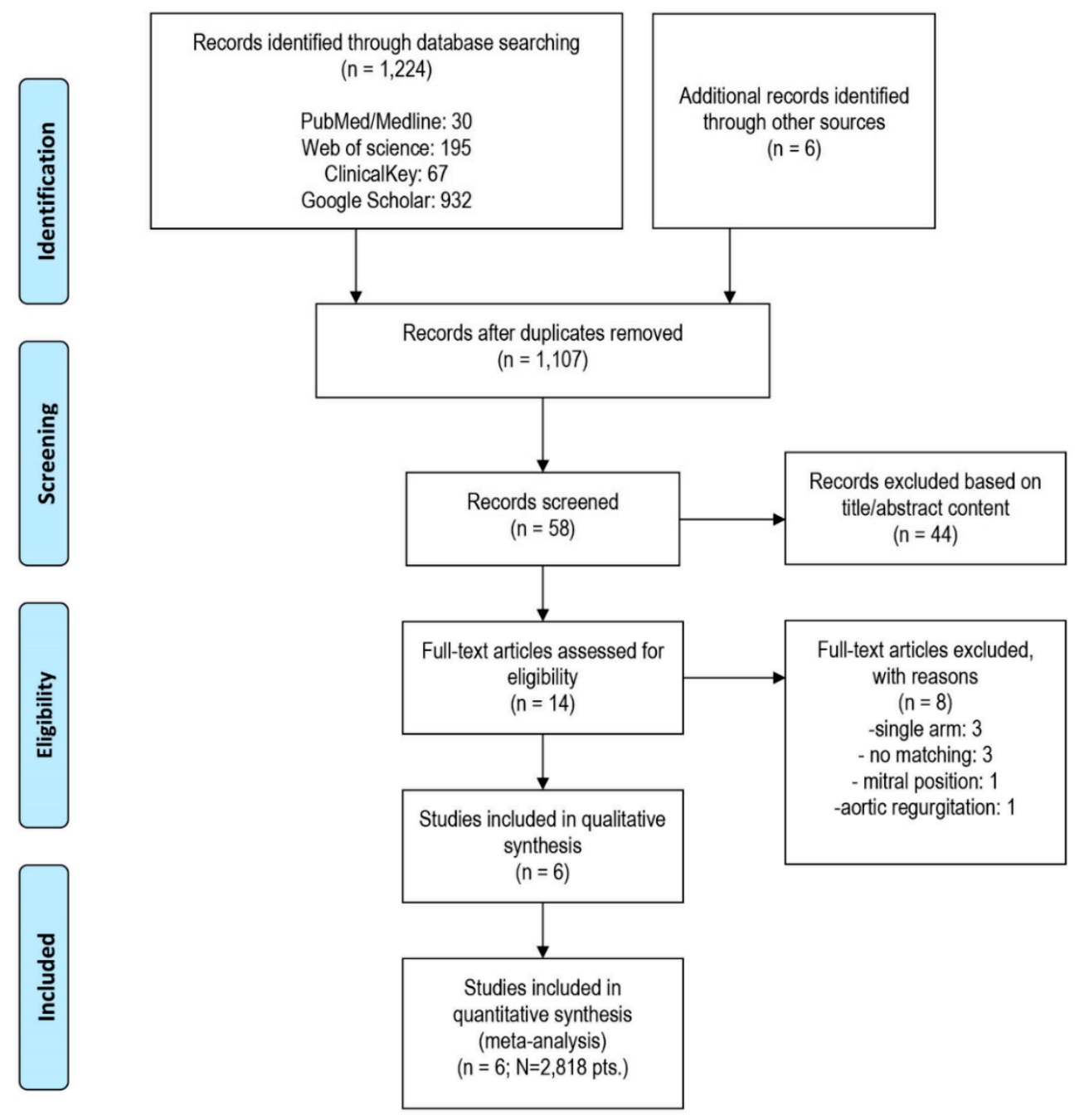

Figure 1. Study selection and inclusion process.

Systematic search of the online databases allowed collection of 58 potentially eligible records that were retrieved for scrutiny. Of those, 52 were further excluded because they were not pertinent to the design of the meta-analysis or did not meet the explicit inclusion criteria. One RCT [14] and five observational studies [15-19] enrolling the total of 2818 patients were eventually included in the analysis. Potential sources of the studies' bias were analyzed with the use of components recommended by the Cochrane Collaboration and ROBINS-I tool, and the results are enclosed as Table A2. Overall, the studies reported moderate risk of bias. Most commonly, biases arose from participants selection for the study by designated heart teams and subjective distribution of the 
participants within the study arms. All but one study [14] lacked a core lab assessment of PVL and central adjudication of clinical events.

Patients were divided into two groups: those treated with ACURATE neo transcatheter valve $(n=1256)$ and SAPIEN 3 transcatheter valve $(n=1562)$. Summary of the valve characteristics is available as Table 1.

Table 1. Valve characteristics and features.

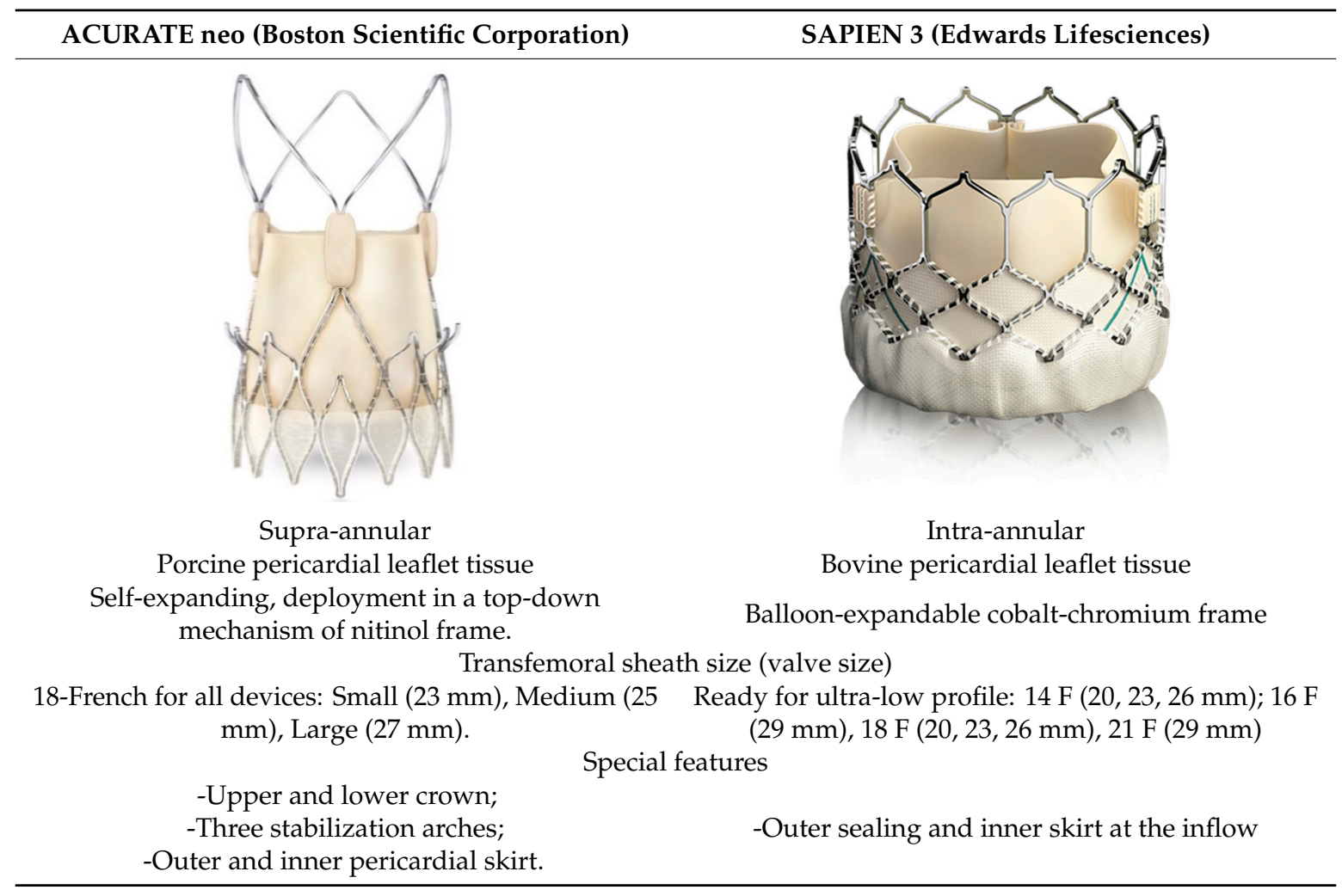

Studies' characteristics, as well as definitions or diagnostic criteria for assessed clinical endpoints, are reported in Table 2. Table A3 lists selection criteria for the procedure and valve, as well as inclusion and exclusion criteria within particular studies. Patients' baseline characteristics and detailed procedural characteristics are available as Tables A4 and A5. All studies reported data on 30-day clinical outcomes; three reported Kaplan-Meier estimates of survival at longer-term follow-ups $[15,16,18]$. 
Table 2. Baseline characteristics of included studies.

\begin{tabular}{|c|c|c|c|c|c|c|c|c|c|c|c|c|}
\hline \multirow[t]{2}{*}{ Study } & \multicolumn{2}{|c|}{ Barth S et al. 2019 [15] } & \multicolumn{2}{|c|}{ Costa et al. 2019 [16] } & \multicolumn{2}{|c|}{$\begin{array}{c}\text { Husser O et al. } 2017 \\
{[17]}\end{array}$} & \multicolumn{2}{|c|}{ Lanz J et al. 2019 [14] } & \multicolumn{2}{|c|}{ Mauri V et al. 2017 [18] } & \multicolumn{2}{|c|}{$\begin{array}{c}\text { Schaefer A et al. } 2017 \\
\text { [19] }\end{array}$} \\
\hline & $\begin{array}{c}\text { ACURATE } \\
\text { neo }\end{array}$ & SAPIEN 3 & $\begin{array}{l}\text { ACURATE } \\
\text { neo }\end{array}$ & SAPIEN 3 & $\begin{array}{l}\text { ACURATE } \\
\text { neo }\end{array}$ & SAPIEN 3 & $\begin{array}{l}\text { ACURATE } \\
\text { neo }\end{array}$ & SAPIEN 3 & $\begin{array}{l}\text { ACURATE } \\
\text { neo }\end{array}$ & SAPIEN 3 & $\begin{array}{l}\text { ACURATE } \\
\text { neo }\end{array}$ & SAPIEN 3 \\
\hline Study period & \multicolumn{2}{|c|}{ 2012-2016 } & \multicolumn{2}{|c|}{$09.2014-02.2018$} & \multicolumn{2}{|c|}{$01.2014-01.2016$} & \multirow{2}{*}{\multicolumn{2}{|c|}{$\begin{array}{l}\text { 02.2017-02.2019 } \\
\text { MC, RCT }\end{array}$}} & \multicolumn{2}{|c|}{$02.2014-08.2016$} & \multicolumn{2}{|c|}{ 2012-2016 } \\
\hline Design & \multicolumn{2}{|c|}{ MC, RCS, PM } & \multicolumn{2}{|c|}{ SC, RCS, PM } & \multicolumn{2}{|c|}{ MC, RCS, PM } & & & \multicolumn{2}{|c|}{ MC, RCS, PM } & \multicolumn{2}{|c|}{ SC, RCS, PM } \\
\hline Number of pts. & 329 & 329 & 48 & 48 & 311 & 622 & 372 & 367 & 92 & 92 & 104 & 104 \\
\hline Age & $81.0 \pm 5.0$ & $81.0 \pm 6.0$ & $82.3 \pm 3.8$ & $83.3 \pm 2.3$ & $81.0 \pm 6.0$ & $81.0 \pm 6.0$ & $82.6 \pm 4.3$ & $83.0 \pm 3.9$ & $82.8 \pm 6.5$ & $81.9 \pm 5.3$ & $81.7 \pm 5.5$ & $81.2 \pm 6.2$ \\
\hline Female (\%) & \multicolumn{2}{|c|}{ NR } & 70.8 & 68.8 & 60.8 & 55.3 & 59.0 & 55.0 & 92.4 & 92.4 & 69.2 & 65.4 \\
\hline $\operatorname{BMI}\left(\mathrm{kg} / \mathrm{m}^{2}\right)$ & $28.7 \pm 5.5$ & $28.4 \pm 5.8$ & $27.8 \pm 4.6$ & $27.1 \pm 3.9$ & $27.0 \pm 5.0$ & $27.0 \pm 5.0$ & $27.3 \pm 4.4$ & $27.9 \pm 4.7$ & $27.3 \pm 5.5$ & $26.0 \pm 4.7$ & $27.1 \pm 5.1$ & $26.8 \pm 5.0$ \\
\hline STS-PROM (\%) & \multicolumn{2}{|c|}{ NR } & $4.0 \pm 3.3$ & $3.8 \pm 1.7$ & \multicolumn{2}{|c|}{ NR } & $3.7 \pm 1.8$ & $3.7 \pm 1.9$ & \multicolumn{2}{|c|}{ NR } & $5.8 \pm 3.8$ & $5.4 \pm 3.6$ \\
\hline Logistic EuroSCORE (\%) & $18.8 \pm 14.7$ & $19.1 \pm 13.6$ & NR & NR & $18.0 \pm 10.0$ & $18.0 \pm 12.0$ & $\mathrm{NR}$ & NR & $16.2 \pm 8.8$ & $16.6 \pm 8.8$ & $15.9 \pm 9.3$ & $13.7 \pm 9.0$ \\
\hline NYHA III/IV (\%) & 79.0 & 78.1 & \multicolumn{2}{|c|}{ NR } & 256 & 489 & 77.0 & 73.0 & \multicolumn{2}{|c|}{ NR } & 86.5 & 88.5 \\
\hline $\mathrm{EF}(\%)$ & $53.0 \pm 13.0$ & $54.0 \pm 15.0$ & $54.5 \pm 9.7$ & $56.1 \pm 9.7$ & NR & NR & $56.4 \pm 11.1$ & $57.1 \pm 10.7$ & $59.0 \pm 8.0$ & $59.0 \pm 10.0$ & NR & NR \\
\hline $\mathrm{EF}<35 \%(\%)$ & 9.4 & 10.3 & \multicolumn{2}{|c|}{ NR } & 5.8 & 5.5 & \multicolumn{2}{|c|}{ NR } & \multicolumn{2}{|c|}{ NR } & $26.0 *$ & $22.1^{1}$ \\
\hline $\begin{array}{c}\text { Mean aortic gradient } \\
(\mathrm{mmHg})\end{array}$ & $44.0 \pm 15.0$ & $45.0 \pm 14.0$ & $51.3 \pm 14.5$ & $51.3 \pm 17.2$ & $45.0 \pm 15.0$ & $44.0 \pm 16.0$ & $42.9 \pm 17.2$ & $41.5 \pm 15.1$ & $46.0 \pm 16.0$ & $47.0 \pm 16.0$ & $35.9 \pm 16.6$ & $37.6 \pm 16.7$ \\
\hline $\begin{array}{c}\text { Aortic annulus diameter } \\
(\mathrm{mm})\end{array}$ & $21.0 \pm 2.0$ & $21.0 \pm 3.0$ & \multicolumn{2}{|c|}{ NR } & \multicolumn{2}{|c|}{ NR } & $23.6 \pm 1.6$ & $23.7 \pm 1.6$ & \multicolumn{2}{|c|}{ NR } & $24.5 \pm 2.5$ & $25.3 \pm 2.6$ \\
\hline Access site (\%) & $\begin{array}{l}\text { TF } 74.5, \\
\text { TA } 25.5\end{array}$ & $\begin{array}{l}\text { TF } 75.7, \\
\text { TA } 24.3\end{array}$ & TF 100.0 & TF 100.0 & TF 100.0 & TF 100.0 & $\begin{array}{l}\text { TF 99.0, } \\
\text { TA }<1.0\end{array}$ & TF 100.0 & TF 100.0 & TF 100.0 & TF 100.0 & TF 100.0 \\
\hline $\begin{array}{l}\text { VARC-2 outcomes } \\
\text { definitions }\end{array}$ & \multicolumn{2}{|c|}{ yes } & \multirow{2}{*}{\multicolumn{2}{|c|}{$\begin{array}{l}\text { Yes } \\
12\end{array}$}} & \multirow{2}{*}{\multicolumn{2}{|c|}{ yes }} & ye & & & & $\mathrm{y}$ & es \\
\hline Follow-up (months) & $10.8 \pm 9.7$ & $12.2 \pm 9.9$ & & & & & 1 & & 12.7 & \pm 2.6 & 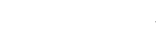 & \\
\hline
\end{tabular}

$1<44 \%$ EF; RCT, randomized control trial; SC, single center; MC, multi center; RCS, retrospective cases series; PM, propensity matching; NYHA, New York Heart Association; STS-PROM, Society of Thoracic Surgeons Predicted Risk of Mortality; EuroSCORE, European System for Cardiac Operative Risk Evaluation; VARC, Valve Academic Research Consortium; EF, ejection fraction; TF, trans femoral; TA, trans apical; NR, not reported. In bold are highlighted the variables that differed significantly between study groups. 


\subsection{Patients Characteristic}

Groups treated with ACURATE neo and SAPIEN 3 did not differ regarding patients' age $(P=0.363)$, body mass index $(P=0.708)$, NYHA III/IV status $(P=0.115)$ or left ventricle ejection fraction $(P=0.178)$. No difference was found in the baseline logistic EuroSCORE as well $(P=0.749)$. SAPIEN 3 group included significantly fewer female individuals, $59.7 \%$ vs. $64.1 \%$, respectively $(P=0.037)$. Aortic valve baseline echo-parameters, i.e., mean trans-aortic gradient were comparable: $43.4 \pm 15.8$ vs. $43.6 \pm 15.5 \mathrm{mmHg}(P=0.861)$ in ACURATE neo and SAPIEN 3, respectively (Figure 2$)$, although the aortic annulus plane area were on average $4 \mathrm{~mm}^{2}$ smaller in the ACURATE neo recipients $439.7 \pm 62.4$ vs. $446.7 \pm 76.3 ; P=0.037$ as compared to SAPIEN 3 . Transfemoral access was mostly widely employed during TAVR procedure; in five studies, it was used exclusively [14,16-19]. Barth et al. [15] included both transfemoral and transapical access in $75.7 \%$ vs. $24.3 \%$ and $74.5 \%$ vs. $25.5 \%$ for ACURATE neo and SAPIEN 3, respectively. For the transapical approach, ACUARATE TA device was used.

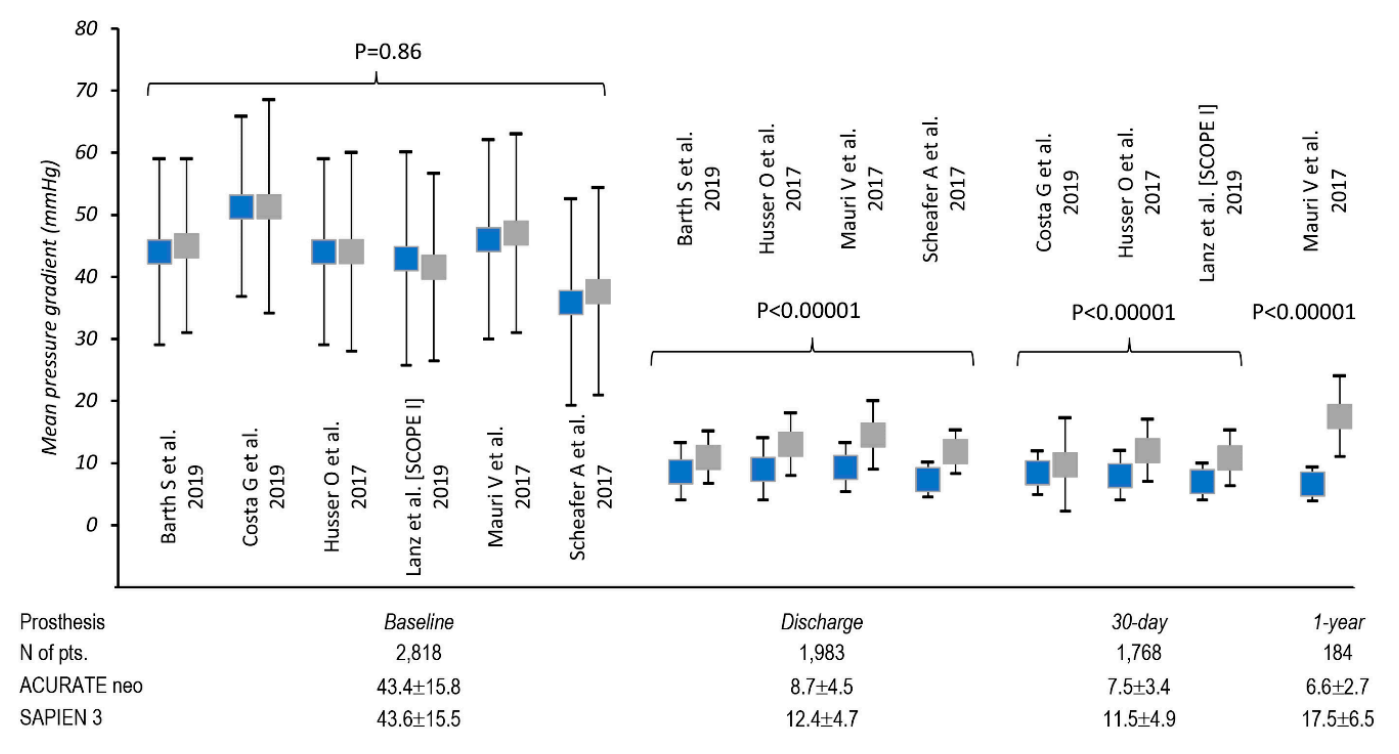

Figure 2. Analysis of mean transaortic gradients before and after transcatheter aortic valve replacement (TAVR).

\subsection{Procedural Outcomes}

Five studies [14,15,17-19] and 2722 patients contributed to the analysis of procedural outcomes between two devices. Both predilatation and postdilatation were more common with ACURATE neo valve; predilatation was necessary in 1124/1271 (88.4\%) of cases as compared to 801/1514 (52.9\%); RR 2.05, 95\% CI, $\left.(1.44,2.94) P<0.0001 ; I^{2}=97 \%\right)$; postdilatation: RR 3.10, 95\% CI, $(2.01,4.77) P<0.00001$; $I^{2}=88 \%$ ) with respective rates of $45.3 \%$ vs. $17.2 \%$ for ACURATE neo and SAPIEN 3, respectively. Figure A1 and A2. The procedures performed with ACURATE neo required significantly greater amount of contrast: $130.3 \pm 56.1 \mathrm{~mL}$ vs. $109.7 \pm 50.3 \mathrm{~mL}(\mathrm{MD} 18.2295 \% \mathrm{CI},(10.04,26.40) \mathrm{mL}$; $P<0.0001)$. Figure A3). Four studies $[14,15,17,19]$ including 1116 ACURATE neo and 1411 SAPIEN 3 cases provided data on procedure duration, which on average 3 minutes longer in the former: $60.1 \pm 28.6 \mathrm{~min}$. vs. $56.5 .9 \pm 26.0 \mathrm{~min}$. (MD 3.06, 95\% CI, $(-0.66,6.76) \mathrm{min}$ ) without reaching statistical significance (Figure A4). Use of $>1$ valve was necessary in 35 cases (26 ACURATE neo vs. nine SAPIEN 3; RR 3.24, 95\% CI, $\left.(1.47,7.13) P=0.004 ; I^{2}=0 \%\right)$. Incidence of cardiac tamponade was reported in three studies $[14,15,18]$ with respective event rates of $1.0 \%$ vs. $0.7 \%$ for ACURATE neo and SAPIEN 3 valves: RR 1.17, 95\% CI, $(0.52,2.63) P=0.70 ; I^{2}=0 \%$. Early procedural complications included the following: coronary obstruction in three ACURATE neo patients and total of eight annular ruptures, 20 conversions to surgery and 20 valve malpositionings without differences between two devices. 


\subsection{Clinical Outcomes}

Six studies [14-19] enrolling 2818 patients contributed data for the analysis of early safety as defined by VARC-2; with the corresponding rates of 13.9\% (174/1256) and 12.6\% (197/1562) for ACURATE neo and SAPIEN 3 valves, respectively, there were no statistical differences between two devices (RR 1.15, 95\% CI, $\left.(0.94,1.40) P=0.16 ; I^{2}=0 \%\right)$ and pooled estimates of RCT and PS-matched studies in subgroup analysis $\left(P_{\text {interaction }}=0.47\right)($ Figure 3a). In the pooled analysis of device success (five studies included (2634 patients.)), there were no differences between two types of valve in the pooled analysis: RR 1.01, 95\% CI, $(0.92,1.10)$ $\left.P=0.89 ; I^{2}=89 \%\right)$. Analyzed separately, there were strong between-subgroup differences between RCT and pooled estimate from PS-matched studies: RR 1.44, 95\% CI, $(1.24,1.66) ; P<0.00001 ; I^{2}=$ NA and RR $0.95,95 \%$ CI, (0.91, 0.99); $P=0.01 ; I^{2}=47 \%$ with $P_{\text {interaction }}<0.00001$ (Figure $3 b$ ).

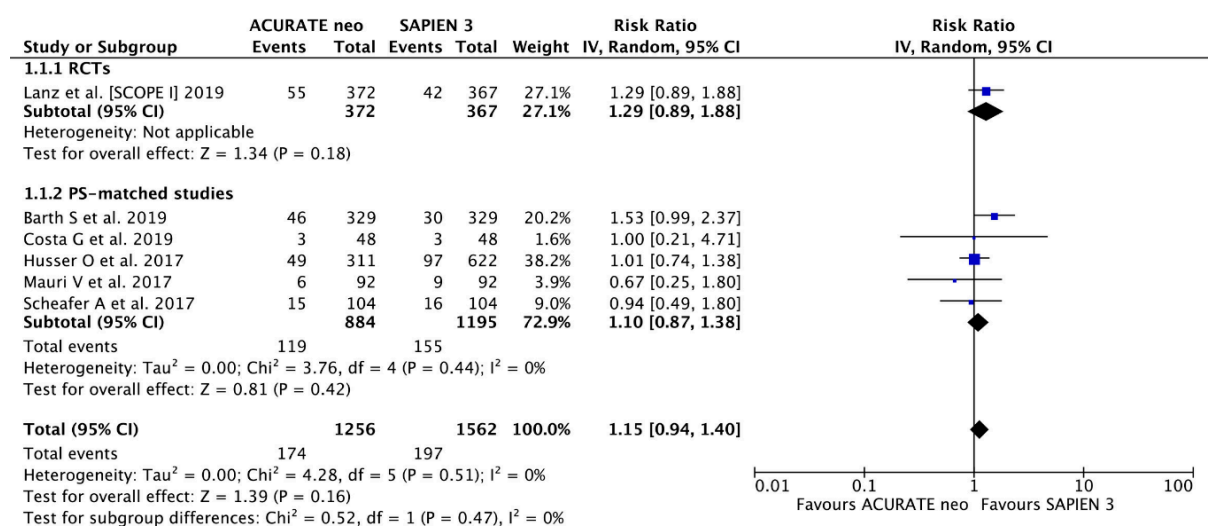

(a)

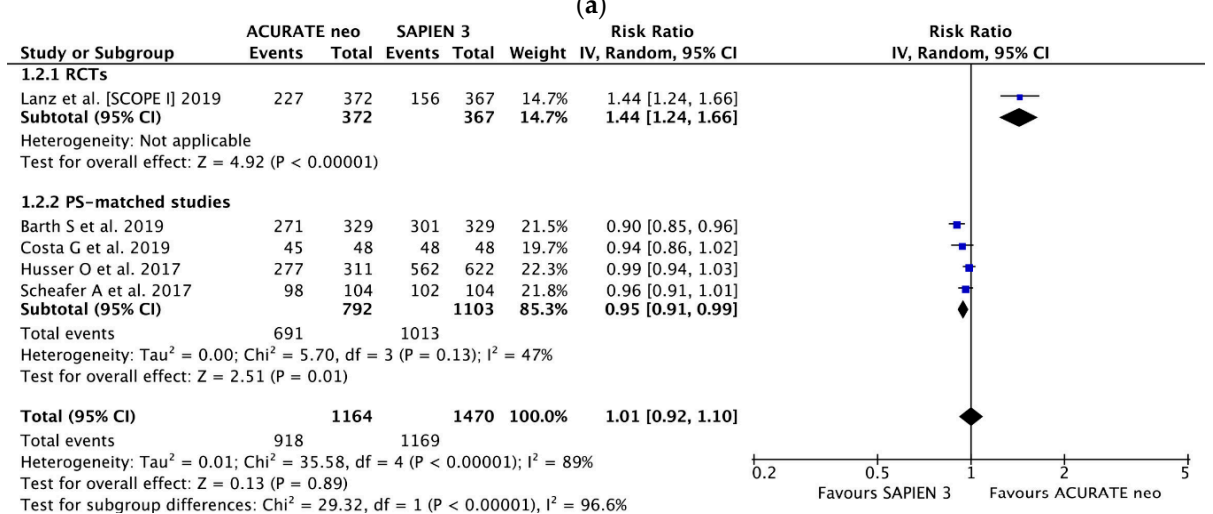

(b)

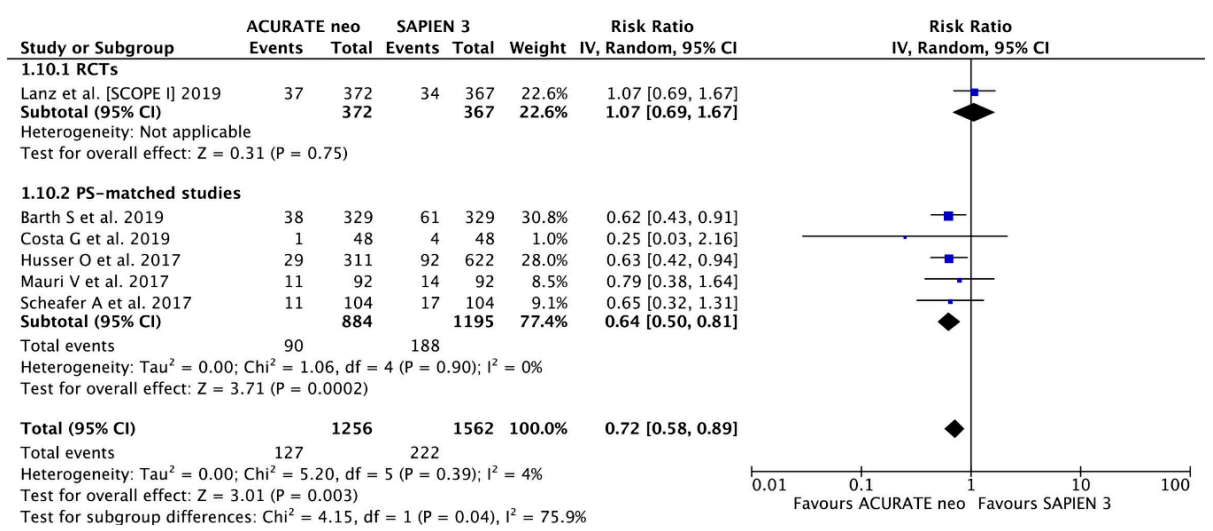

(c)

Figure 3. Individual and summary risk ratios with corresponding $95 \%$ confidence intervals for the comparison of ACURATE neo vs. SAPIEN 3 in the analysis of clinical outcomes: (a) early safety, (b).device success and (c) permanent pacemaker implantation. 
There were no differences between ACURATE neo and SAPIEN 3 valves in terms of risk of major vascular complications (RR 1.21, 95\% CI, $(0.89,1,65) ; P=0.23 ; I^{2}=6 \%$; Figure A5), acute kidney injury (RR 1.28, 95\% CI, $(0.71,2,31) ; P=0.42 ; I^{2}=15 \%$; Figure A6), periprocedural myocardial infarction (RR 1.76, 95\% CI, $(0.36,8.47) ; P=0.428 I^{2}=0 \%$; Figures A7 and A8), stroke (RR 0.95, 95\% CI, (0.57, 1.57 ); $P=0.84 I^{2}=0 \%$; Figures A9 and A10), and serious bleeding events (RR 1.23, 95\% CI, $(0.95,1.61) ; P=$ $0.12 ; I^{2}=0 \%$; Figure A11).

Based on the data from six studies (2818 pts.), PPI was required nearly $30 \%$ less often after ACURATE neo implantation as compared to SAPIEN 3 (RR 0.72, 95\% CI, $(0.58,0.89$ ); $P=0.003$; $I^{2}=75.9 \%$ ) with corresponding frequency of $10.1 \%$ vs. $14.2 \%$, respectively (Figure 3c). Importantly, the estimates derived from SCOPE I differed from the pooled estimates $\left(P_{\text {interaction }}=0.04\right)$ with higher rates of PPI observed in SAPIEN 3 arm in PS-matched studies (9.3\% vs. 15.8\%) Table A6 lists the VARC-2 derived quality criteria for PPI appraisal

\subsection{Functional Outcomes}

With five studies [14-16,18,19] and 1885 patients included, mild PVL occurred less frequently in SAPIEN 3 recipients, 28.0\% (263 of 940), compared to ACURATE neo group, 45.5\% (430 of 945); (RR 1.60, $95 \% \mathrm{CI},(1.40,1.84) P<0.00001 ; I^{2}=14 \%$ ) (Figure $\left.4 a\right)$. Moderate-to-severe PVL was uncommon in the entire series (6.5\%); however, there was a significant 3.7-fold increase in moderate-to-severe PVL risk with ACURATE neo implantation: (RR 3.70, 95\% CI, $(2.04,6.70) P<0.0001 ; I^{2}=53 \%$ ) (Figure $4 b$ ) and corresponding incidence of $11.7 \%(147 / 1,256)$ and $2.3 \%(36 / 1,562)$ in ACURATE neo and SAPIEN 3 valves.

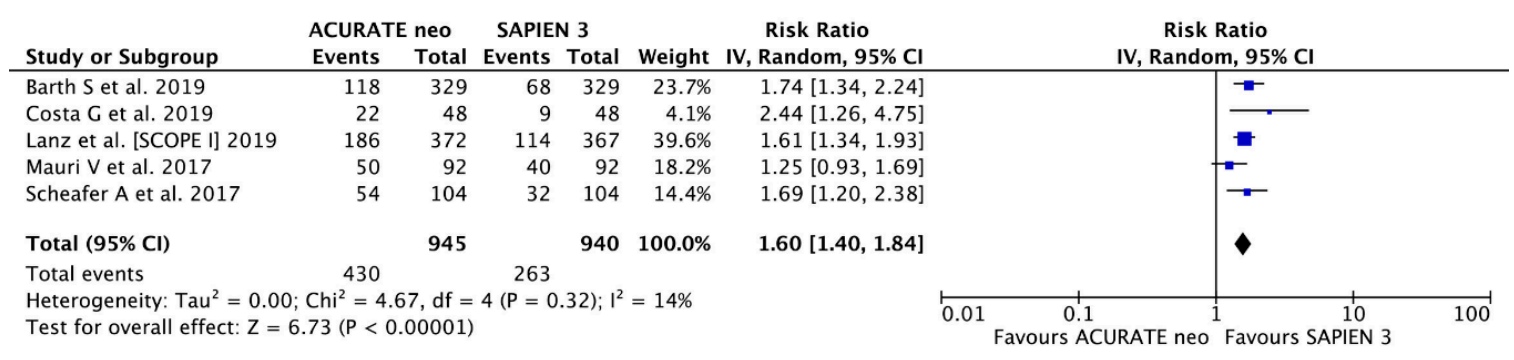

(a)

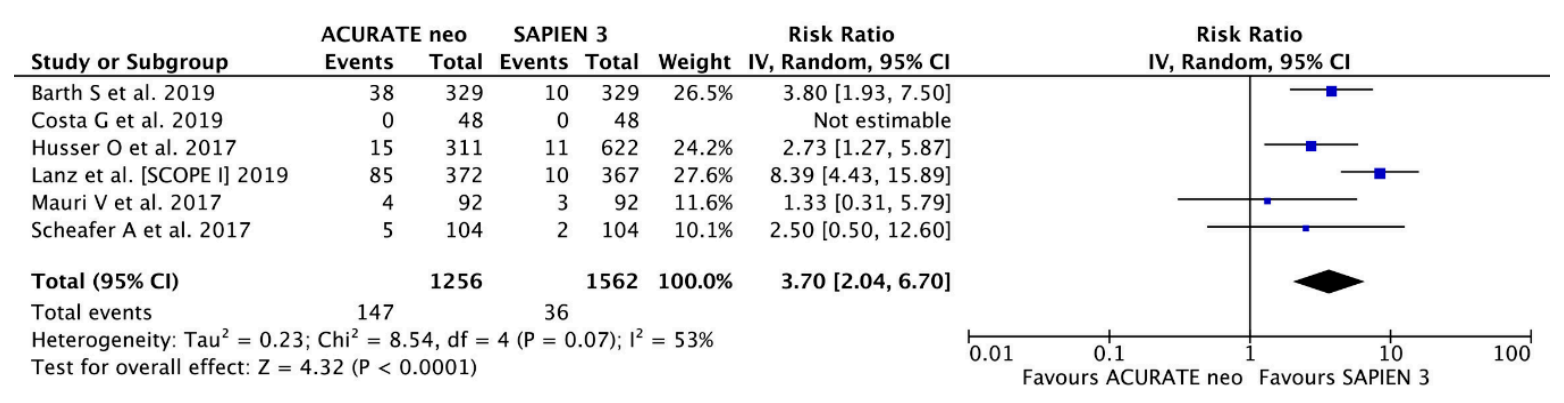

(b)

Figure 4. Individual and summary risk ratios with corresponding 95\% confidence intervals for the comparison of ACURATE neo vs. SAPIEN 3 in the analysis of functional outcomes: (a) mild and (b) moderate-to-severe paravalvular leak.

Data regarding postprocedural transaortic gradient came from all six studies with 2818 patients. Mauri et al. [18] reported on 1-year transaortic gradients as well. (Figure 2). Mean postprocedural transaortic gradients were higher in SAPIEN 3 patients both at discharge and at 30 days post-op: $12.4 \pm 4.7$ vs. $8.7 \pm 4.5 \mathrm{mmHg}(P<0.00001)$ and $11.5 \pm 4.9$ vs. $7.5 \pm 3.4 \mathrm{mmHg}(P<0.00001)$ respectively. 


\subsection{All-Cause Mortality}

Six studies reported on 30-day all-cause mortality. Overall, 61 (2.2\%) patients died within the first 30 days, with respective rates of $2.9 \%$ and $1.6 \%$ in ACURATE neo and SAPIEN 3 groups; ACURATE neo was associated with $77 \%$ higher 30 -day mortality risk (RR 1.77, 95\% CI, $(1.03,3.04) ; P=0.04 ; I^{2}=0 \%$ (Figure 5a and Appendix Figure A12). A random-effects meta-regression was fitted, counter-opposing all-cause mortality risk ratio against the risk difference of moderate-to-severe PVL; there was a trend for higher 30-day mortality rates with higher incidence of moderate-to-severe PVL (beta $=0.023 ; P=0.093$ ) (Figure 5b); similarly, a meta-regression was fitted with all-cause mortality risk ratio against the mean annulus area in the ACURATE neo arm showing a trend for lower between devices mortality ratio in smaller annuli (beta $=22.078 ; P=0.098$ ) (Figure 5c).

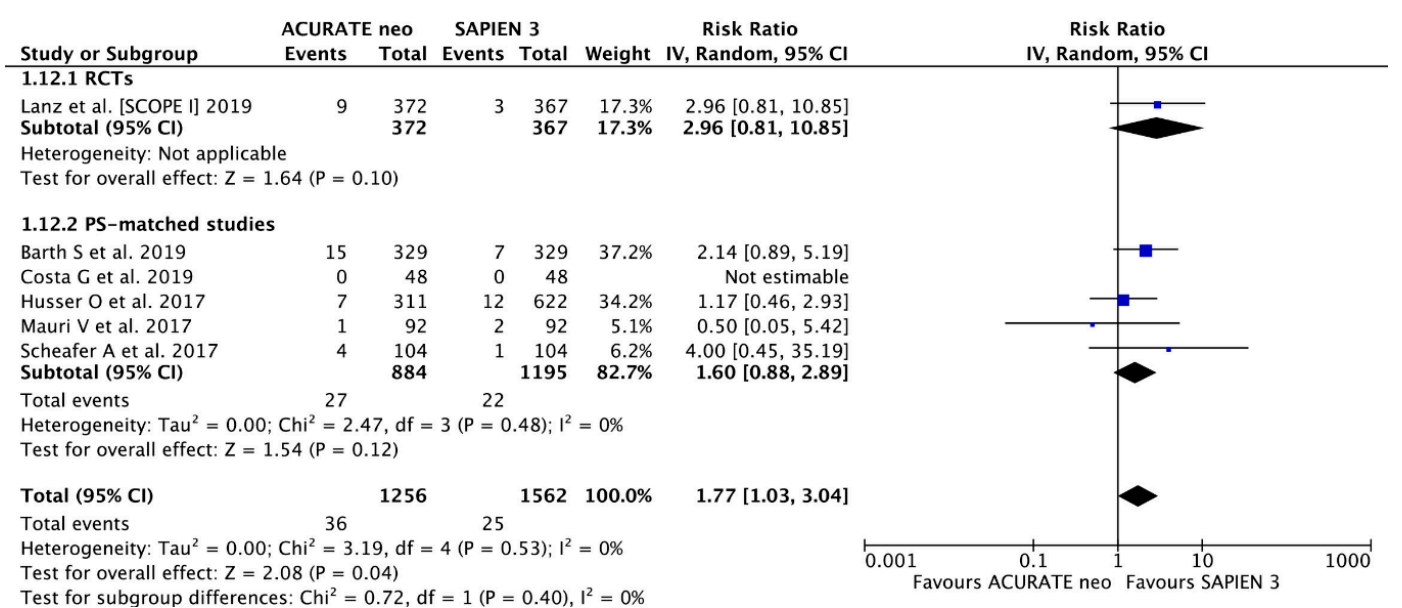

(a)

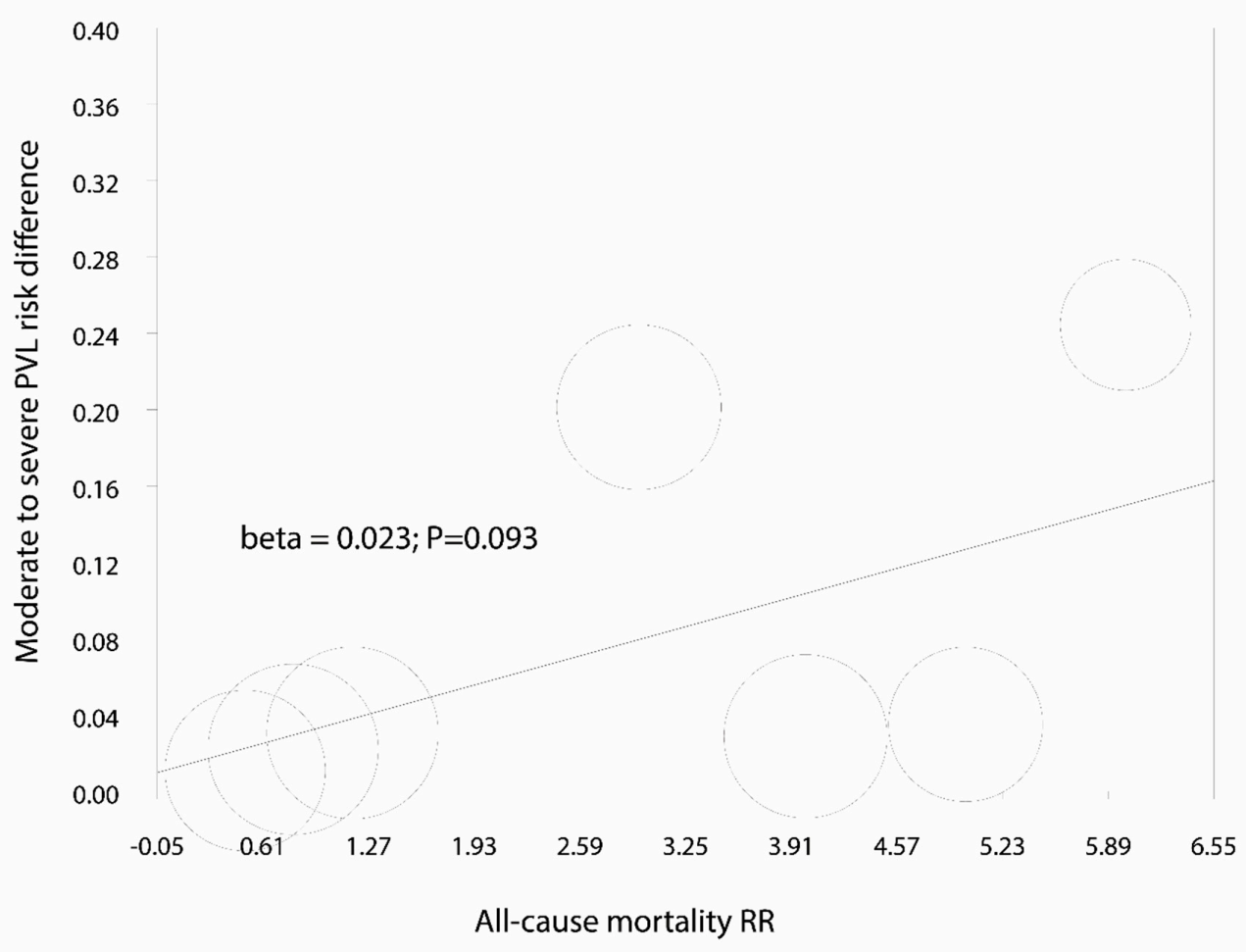

(b)

Figure 5. Cont. 


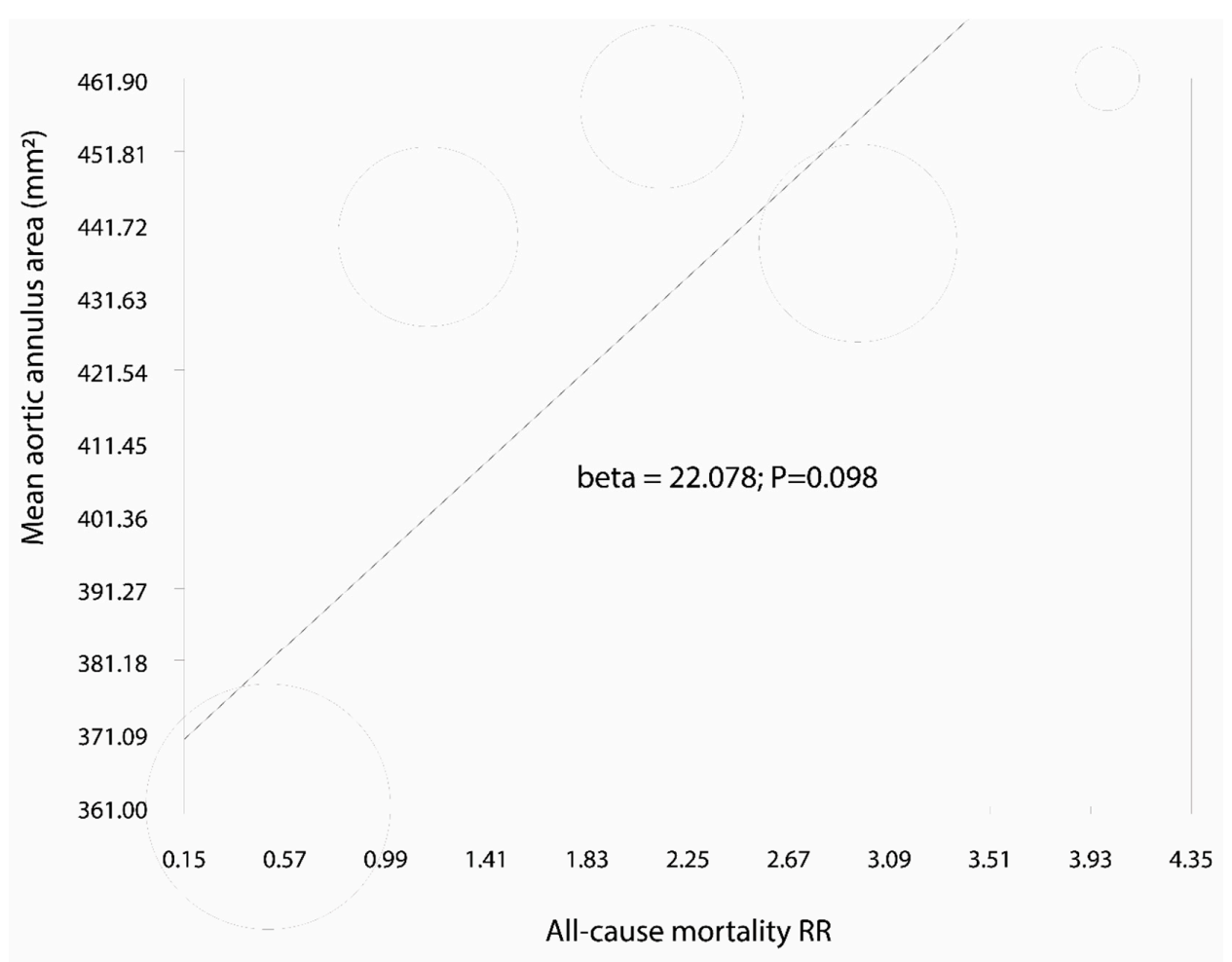

(c)

Figure 5. Individual and summary risk ratios with corresponding $95 \%$ confidence intervals for the comparison of ACURATE neo vs. SAPIEN 3 in the analysis of (a) 30-day all-cause mortality; (b,c) meta regression analyses.

\section{Discussion}

To the best of our knowledge, this is the first systematic review and meta-analysis of observational trials comparing major procedural, short-term clinical and functional outcomes between the ACURATE neo and SEPIEN 3, the next-generation transcatheter valves designed to minimize shortcomings of the earlier-generation devices. Our analysis, by pooling data from one RCT and five PS-matched studies, demonstrated excellent data regarding short-term performance of both devices. Compared populations of patients were well balanced with respect to baseline characteristics and severity of underlying valvular disease. Main findings of the current study are that the ACURATE neo implantation as compared to SAPIEN 3 was associated with lower transvalvular gradients and lower risk of permanent pacemaker implantation. Other clinical endpoints which included vascular complications, AKI, as well as life threatening and major bleeding; stroke and MIs did not differ between the two groups. The use of ACURATE neo procedures were significantly longer and required a greater amount of contrast volume. Device success and early safety combined endpoints, as defined by VARC-2 criteria, were, however, similar regardless the type of valve implanted. Importantly, the current study revealed significantly higher rates of both mild and moderate-to-severe PVL with ACURATE neo as compared to SAPIEN 3 and the latter were indirectly associated with worse survival observed in ACURATE neo group.

Previous observational studies [15-21] and, among them, the SAVI-TF (Symetis ACURATE neo Valve Implantation Using Transfemoral Access) registry $[29,30]$ reported on excellent short-term outcomes with low complications and, in particular, PPI rates in ACURATE neo valve attributable to the design of the prosthesis. The particularly low gradients also contributed to the similar or better rates of device success for ACURATE neo and SAPIEN 3 in propensity matched comparisons. Whether the abovementioned benefits would hold true in randomized populations and further translate into improved clinical outcomes was investigated in the Safety and Efficacy of the Symetis ACURATE 
Neo/TF Compared to the Edwards SAPIEN 3 Bioprosthesis trial (SCOPE I) [14]. Interestingly, the ACURATE neo valve failed to meet noninferiority for its primary endpoint of combined at 30 days against the balloon-expandable SAPIEN 3 (Edwards Lifesciences) valve. Moreover, secondary analyses demonstrated SAPIEN 3 to be superior for the composite safety and efficacy endpoint, driven by less stage 2 or 3 acute kidney injury and less paravalvular leak. Valve dysfunction requiring repeat interventions was also less common at 30 days. In particular, findings on device success need to be addressed, since the rates varied largely between RCT and the remaining PS-matched studies driven by higher patient prosthesis mismatch in the SAPIEN 3 group $(P<0.00001)$. Indeed, median mean transvalvular gradient was lower, and the median mean aortic valve area was larger, in the ACURATE neo, compared to the SAPIEN 3 group, at follow-up echocardiography in the SCOPE I trial. This may have been partially due to the fact that sizing and thus the choice of the valve process were different in the SCOPE I and the remaining studies. Some residual bias despite propensity score matching also cannot be excluded. In fact, Mauri et al. [18] reports on the sizing category was based on perimeter for ACURATE neo and annular area for SAPIEN 3, then all patients received ACURATE neo size S or SAPIEN $323 \mathrm{~mm}$. In the study by Husser et al. [17] after PS-matching, there remained a $P=0.003$ difference in aortic annular area; Schaefer et al. [19] reports aortic annulus size to have presented significant differences for area derived aortic annulus diameter $(23.9 \pm 2.8$ vs. $24.8 \pm 2.6$ $\mathrm{mm} ; P=0.02)$ and perimeter-derived aortic annulus diameter $(24.5 \pm 2.5 \mathrm{vs} .25 .3 \pm 2.6 \mathrm{~mm} ; P=0.02)$, which, in consequence, led to oversizing in the ACURATE neo and undersizing SAPIEN $3(1.5 \pm 6.6$ vs. $-0.9 \pm 6.4 ; P=0.01$ for cover index). Further, only in the SCOPE I trial, both the clinical events and functional assessment details were adjudicated by independent core lab. Independently, there were fewer PPI necessary after ACURATE neo in the PS-matched studies; since not confirmed in the SCOPE I, the supra-annular positioning of the valve must have had played, however, a much less important role than expected, and the lower PPI rates originating from skewed valve-size selection and positioning of the valve in the annulus [29]. More importantly, though, SCOPE I trial, by design, excluded over 300 patients with excessive calcification of aortic valve or left ventricular outflow tract (LVOT), which was not the case in remaining studies included in the current analysis. Presence of calcifications in both aortic annulus and LVOT could have accounted for much higher rates of PPI in the SAPIEN 3 arms across included PS-matched studies (average PPI incidence rate of $15.8 \%$ ) as compared to SCOPE I trial with $9.3 \%$ rate, similarly to what has been already demonstrated for SAPIEN 3 in another meta-analysis by the same group [30].

Conversely to the abovementioned, yet still contributing to device success rates, was the higher incidence of moderate-to-severe PVL in the ACURATE neo valve, which was confirmed also in the current meta-analysis. In the next-generation devices, improved by addition an external sealing cuff or a skirt, the frequencies of mild and moderate-to-severe PVL became significantly lower as compared with the earlier-generation valves. The pooled occurrence of more than mild PVL decreased from $6.9 \%$ SAPIEN XT to $1.6 \%$ in SAPIEN 3 valve, as in a meta-analysis by Ando et al. with 2498 patients [31]. The PARTNER II SAPIEN-3 trial, which assessed early outcomes after TAVR in inoperable, high-risk and intermediate-risk patients with severe aortic stenosis, showed moderate-to-severe PVL in 3.4\% and mild in $40.7 \%$ of the cases [32]. The abovementioned improvements seen in next-generation devices seem not to be the case with ACURATE neo; in the meta-analysis, we found $11.7 \%$ incidence of moderate-to-severe PVL in the ACURATE neo arm, nearly fourfold higher than in SAPIEN 3 and mild PVL in $45.5 \%$ cases, translating into $60 \%$ increased risk. Unlike the current findings, SAVI TF registry showed $4.1 \%$ of $>$ mild PVL in 1000 patients treated with ACURATE neo which is within ranges observable for other devices [33-38]. Postdilatation was performed in $44.8 \%$ of the patients in that series, and this percentage is also comparable to $40.4 \%-51.9 \%$ in the current analysis, and therefore, theoretically, should not influence the outcome; on the other hand, Barth et al. [15] reports lower $>$ mild PVL rates in one of participating centers (C) that used "zero tolerance of more than mild paravalvular leak" policy and postdilated more frequently than other centers $(52.7 \%$ as compared to $12.3 \%$ and $33.3 \%$ ), which translated to $3.4 \%$ rate of $>$ mild PVL (as compared to $6.0 \%$ and $34.1 \%$ in the remaining 
centers). Interestingly, this center was the one to demonstrate highest one-year survival (87.4\% (95\% CI: 79.6-92.3) compared to 75.4\% (95\% CI: 60.4-85.3) and 81.3\% (95\% CI: 70.1-88.6)). Corroborating these estimates on larger scale and also in shorter follow-up, the current meta-analysis found an indirect link between increased rates of $>$ mild PVL and higher mortality in the ACURATE neo arm at 30 days. While the presence of residual $>$ mild PVL has been long shown to be associated with increased mortality in the long-term $[39,40]$, the link between $>$ mild PVL and 30-day mortality appears less clear, particularly for next-generation devices [12]. The abovementioned may be of importance given the fact that acute aortic insufficiency of various degree in patients with prior pure aortic stenosis and diminished LV compliance is often a cause of heart-failure exacerbation early in the sequelae [41].

An indirect link to increased mortality with ACURATE neo, as found also in meta-regression of annular area; indeed, lower between-devices mortality risk ratios between ACURATE neo and SAPIEN 3 were shown in patients with smaller annuli. An important hypothesis generated by present meta-analysis is that ACURATE neo performs differently in this setting; since we could not demonstrate excess of annual ruptures, cardiac tamponades, conversions to surgery or other periprocedural complications in either group, the explanation of this phenomenon remains to be elucidated.

Several inherent limitations to the current analysis need to be acknowledged; firstly, the majority of included studies are of an observational nature. Despite accounting for differences in the patients' baseline populations by propensity matching in all of the non-randomized reports, there remain other confounders, like learning curve, operators' experience and decision as of valve size and type that add to the risk of bias. Indeed, it cannot be refused that ACURATE neo was the preferred valve in smaller aortic annuli in PS-matched studies. Secondly, one study [15] reports on outcomes with both transfemoral ACURATE neo and transapical ACURATE TA systems. While similar in stent design and technological features, there are certain, albeit minor, differences in delivery system and biological tissue used in both devices [42]. Thirdly, only half of included studies reported follow-up longer than one month; paucity of data regarding long-term clinical and functional outcomes significantly impedes interpretation of ACURATE neo and SAPIEN 3 clinical suitability. Lastly, all but one study [14] lacked of an external core lab assessment and adjudication of echocardiographic outcomes. Finally, to better visualize the relative advantages of the contemporary-use valve systems, the results of a second similar study, SCOPE II (NCT03192813), will compare the ACURATE neo to the EVOLUT R system with respect to a composite of all-cause death and stroke at one year.

\section{Conclusions}

Contemporary evidence shows good short-term implantation outcomes of both ACURATE neo and SAPIEN 3 valves, with no differences in combined endpoints of device success and early safety. Implantation of ACURATE neo was associated with lower transvalvular gradients and lower risk of permanent pacemaker implantation. Moderate-to-severe PVL rates were, however, higher in ACURATE neo valve and were indirectly associated with increased 30-day all-cause mortality.

Author Contributions: Conceptualization, M.G., M.M., D.F., F.J., P.M., G.M.R., P.G.M., A.S. and M.K.; methodology, K.Z., M.P., D.P., J.K., R.L., P.S. and M.K.; software, M.K.; validation, all authors; formal analysis, M.G., G.M.R., P.G.M. and M.K.; investigation, M.G., K.Z., M.P., M.M., D.F., F.J., P.M.; resources, not available; data curation, M.G., G.M.R., P.G.M. and M.K.; writing—original draft preparation, all authors; writing—review and editing, R.L., P.S. and M.K.; visualization, M.K.; supervision, R.L., P.S. and M.K.; project administration, M.K.; funding acquisition, not available. All authors have read and agreed to the published version of the manuscript.

Conflicts of Interest: The authors declare no conflicts of interest. 


\section{Appendix A}

Table A1. Checklist for meta-analyses of observational studies.

\begin{tabular}{|c|c|c|}
\hline Item No. & Recommendation & Reported on Page No. \\
\hline \multicolumn{3}{|c|}{ Reporting of background should include } \\
\hline 1 & Problem definition & 2 \\
\hline 2 & Hypothesis statement & NA \\
\hline 3 & Description of study outcome(s) & $3-11$ \\
\hline 4 & Type of exposure or intervention used & 5 \\
\hline 5 & Type of study designs used & 5 \\
\hline 6 & Study population & 5 \\
\hline \multicolumn{3}{|c|}{ Reporting of search strategy should include } \\
\hline 7 & Qualifications of searchers (e.g., librarians and investigators) & Title page \\
\hline 8 & Search strategy, including time period included in the synthesis and key words & 4, Figure 1 \\
\hline 9 & Effort to include all available studies, including contact with authors & 5 \\
\hline 10 & Databases and registries searched & 5 \\
\hline 11 & Search software used, name and version, including special features used (e.g., explosion) & NA \\
\hline 12 & Use of hand searching (e.g., reference lists of obtained articles) & 5 \\
\hline 13 & List of citations located and those excluded, including justification & NA \\
\hline 14 & Method of addressing articles published in languages other than English & NA \\
\hline 15 & Method of handling abstracts and unpublished studies & NA \\
\hline 16 & Description of any contact with authors & NA \\
\hline \multicolumn{3}{|c|}{ Reporting of methods should include } \\
\hline 17 & $\begin{array}{c}\text { Description of relevance or appropriateness of studies assembled for assessing the hypothesis to be } \\
\text { tested }\end{array}$ & NA \\
\hline 18 & Rationale for the selection and coding of data (e.g., sound clinical principles or convenience) & NA \\
\hline 19 & $\begin{array}{c}\text { Documentation of how data were classified and coded (e.g., multiple raters, blinding and interrater } \\
\text { reliability) }\end{array}$ & NA \\
\hline 20 & Assessment of confounding (e.g., comparability of cases and controls in studies where appropriate) & Table A2 \\
\hline 21 & $\begin{array}{c}\text { Assessment of study quality, including blinding of quality assessors, stratification or regression on } \\
\text { possible predictors of study results }\end{array}$ & Table A2 \\
\hline 22 & Assessment of heterogeneity & 3 \\
\hline 23 & $\begin{array}{l}\text { Description of statistical methods (e.g., complete description of fixed or random effects models, } \\
\text { justification of whether the chosen models account for predictors of study results, dose-response models, } \\
\text { or cumulative meta-analysis) in sufficient detail to be replicated }\end{array}$ & 3 \\
\hline 24 & Provision of appropriate tables and graphics & yes \\
\hline
\end{tabular}


Table A1. Cont.

\begin{tabular}{|c|c|c|}
\hline Item No. & Recommendation & Reported on Page No. \\
\hline \multicolumn{3}{|c|}{ Reporting of results should include } \\
\hline 25 & Graphic summarizing individual study estimates and overall estimate & Figures $3-5$ \\
\hline 26 & Table giving descriptive information for each study included & Table 2 \\
\hline 28 & Indication of statistical uncertainty of findings & $13-14$ \\
\hline \multicolumn{3}{|c|}{ Reporting of discussion should include } \\
\hline 29 & Quantitative assessment of bias (e.g., publication bias) & NA \\
\hline 30 & Justification for exclusion (e.g., exclusion of non-English language citations) & Figure 1 \\
\hline 32 & Consideration of alternative explanations for observed results & $11-13$ \\
\hline 33 & $\begin{array}{c}\text { Generalization of the conclusions (i.e., appropriate for the data presented and within the domain of the } \\
\text { literature review) }\end{array}$ & 14 \\
\hline 34 & Guidelines for future research & NA \\
\hline 35 & Disclosure of funding source & Title page \\
\hline
\end{tabular}

From: Stroup DF, Berlin JA, Morton SC, et al. for the Meta-Analysis of Observational Studies in Epidemiology (MOOSE) Group. Meta-Analysis of Observational Studies in Epidemiology. A Proposal for Reporting. JAMA 2000; 283:2008-2012.

Table A2. Publication bias analysis.

\begin{tabular}{|c|c|c|c|c|c|c|c|c|}
\hline Study (RCT) & $\begin{array}{c}\text { Random } \\
\text { sequence } \\
\text { generation } \\
\text { (selection bias) }\end{array}$ & $\begin{array}{c}\text { Allocation } \\
\text { concealment } \\
\text { (selection bias) }\end{array}$ & $\begin{array}{c}\text { Blinding of } \\
\text { participants } \\
\text { and personnel } \\
\text { (performance bias) }\end{array}$ & \multicolumn{2}{|c|}{$\begin{array}{c}\text { Blinding of } \\
\text { outcome } \\
\text { assessment } \\
\text { (detection bias) }\end{array}$} & $\begin{array}{c}\text { Incomplete } \\
\text { outcome } \\
\text { data (attrition } \\
\text { bias) }\end{array}$ & $\begin{array}{l}\text { Selective } \\
\text { reporting } \\
\text { (reporting bias) }\end{array}$ & $\begin{array}{l}\text { Other } \\
\text { bias }\end{array}$ \\
\hline $\begin{array}{c}\text { Lanz et al. [SCOPE I] } \\
2019 \text { [14] }\end{array}$ & Low & Unclear & High & \multicolumn{2}{|l|}{ Low } & Low & Low & Low \\
\hline $\begin{array}{l}\text { Study (PS-matched } \\
\text { studies) }\end{array}$ & $\begin{array}{l}\text { Bias due to } \\
\text { confounding }\end{array}$ & $\begin{array}{l}\text { Bias in selection of } \\
\text { participants into } \\
\text { the study }\end{array}$ & $\begin{array}{c}\text { Bias in } \\
\text { measurement of } \\
\text { interventions }\end{array}$ & $\begin{array}{l}\text { Bias due to departures } \\
\text { from intended } \\
\text { interventions }\end{array}$ & $\begin{array}{l}\text { Bias due to } \\
\text { missing data }\end{array}$ & $\begin{array}{c}\text { Bias in } \\
\text { measurement } \\
\text { of outcomes }^{1}\end{array}$ & $\begin{array}{c}\text { Bias in } \\
\text { selection of } \\
\text { reported result }\end{array}$ & $\begin{array}{c}\text { Overall } \\
\text { bias }\end{array}$ \\
\hline Barth S et al. 2019 [15] & Serious & Serious & Low & Low & Low & Serious & Low & Moderate \\
\hline Costa G et al. 2019 [16] & Serious & Low & Low & Low & Low & Serious & Low & Moderate \\
\hline Husser O et al. 2017 [17] & Serious & Low & Low & Low & Low & Serious & Low & Moderate \\
\hline Mauri V et al. 2017 [18] & Serious & Low & Low & Low & Low & Serious & Low & Moderate \\
\hline Scheafer A et al. 2017 [19] & Serious & Low & Low & Low & Low & Serious & Low & Moderate \\
\hline
\end{tabular}

${ }^{1}$ When multiple outcomes were reported for a study, the highest level of bias at the outcome level is reported in the table. 
Table A3. Inclusion and exclusion criteria. Choice of procedure and valve-type.

\begin{tabular}{|c|c|c|c|c|}
\hline Study [ref] & Inclusion criteria & Exclusion criteria & $\begin{array}{l}\text { Selection criteria for the } \\
\text { procedure }\end{array}$ & Selection criteria for the valve \\
\hline Barth S et al. 2019 [15] & $\begin{array}{l}\text { Patients received either the } \\
\text { ACURATE/ACURATE neo } \\
\text { prostheses }(n=591) \text { or the } \\
\text { SAPIEN } 3 \text { prosthesis }(n=715) \text {. }\end{array}$ & $\begin{array}{l}\text { Through nearest neighborhood } \\
\text { matching with exact allocation for } \\
\text { access route and center, pairs of } 329 \\
\text { patients ( } 250 \text { transfemoral, } 79 \\
\text { transapical) per group were } \\
\text { determined. }\end{array}$ & Not reported. & Not reported. \\
\hline Costa et al. 2019 [16] & $\begin{array}{l}\text { All the patients treated with } \\
\text { SAPIEN 3, Evolut R, or } \\
\text { ACURATE neo, which could } \\
\text { have indifferently received all } \\
\text { the three devices according to } \\
\text { manufacturer sizing indications. }\end{array}$ & $\begin{array}{l}\text { Patients who did not performed } \\
\text { pre-TAVI multi-detector computed } \\
\text { tomography assessment }(\mathrm{n}=169), \\
\text { patients who had a valve-in- valve } \\
\text { implantation in a failed aortic } \\
\text { bioprosthesis }(\mathrm{n}=21), \text { patients with } \\
\text { bicuspid aortic valve }(\mathrm{n}=28), \text { and } \\
\text { pure aortic regurgitation }(\mathrm{n}=1) .\end{array}$ & Not reported. & Not reported. \\
\hline Husser O et al. 2017 [17] & $\begin{array}{l}\text { Patients with symptomatic, } \\
\text { severe stenosis of the native } \\
\text { aortic valve were treated with } \\
\text { transfemoral TAVI using } \\
\text { ACURATE neo }(n=311) \text { or } \\
\text { SAPIEN } 3(n=810) \text { at } 3 \text { centers } \\
\text { in Germany. }\end{array}$ & Not reported. & $\begin{array}{l}\text { The interdisciplinary heart team } \\
\text { discussed all cases and } \\
\text { consensus was achieved } \\
\text { regarding the therapeutic } \\
\text { strategy. }\end{array}$ & $\begin{array}{l}\text { The interdisciplinary heart team } \\
\text { discussed all cases and } \\
\text { consensus was achieved } \\
\text { regarding the therapeutic } \\
\text { strategy. }\end{array}$ \\
\hline
\end{tabular}


Table A3. Cont.

\begin{tabular}{|c|c|c|c|c|}
\hline Study [ref] & Inclusion criteria & Exclusion criteria & $\begin{array}{l}\text { Selection criteria for the } \\
\text { procedure }\end{array}$ & Selection criteria for the valve \\
\hline Lanz J et al. 2019 [14] & $\begin{array}{l}\text { Patients aged } 75 \text { years or older. } \\
\text { With severe aortic stenosis } \\
\text { defined by an aortic valve area } \\
\text { (AVA) }<1 \mathrm{~cm}^{2} \text { or AVA indexed } \\
\text { to body surface area of }<0 \cdot 6 \\
\mathrm{~cm}^{2} / \mathrm{m}^{2} \text {. Symptomatic (NYHA } \\
\text { functional class }>\text { I, angina or } \\
\text { syncope). At increased risk for } \\
\text { mortality if undergoing SAVR } \\
\text { as determined by: - the heart } \\
\text { team OR - an STS-PROM score }> \\
10 \% \text { OR - a Logistic EuroSCORE } \\
>20 \% \text {. Heart team agrees on } \\
\text { eligibility for participation. } \\
\text { Aortic annulus perimeter } 66-85 \\
\text { mm AND area } 338-573 \text { mm } \\
\text { based on multi-slice computed } \\
\text { tomography. Minimum } \\
\text { diameter of arterial } \\
\text { aorto-iliac-femoral axis on one } \\
\text { side: } \geq 5 \cdot 5 \text { mm. Patient } \\
\text { understand the purpose, } \\
\text { potential risks and benefits of } \\
\text { the trial, is able to provide } \\
\text { written informed content and } \\
\text { willing to participate in all parts } \\
\text { of the follow-up. }\end{array}$ & $\begin{array}{l}\text {-Non-valvular, congenital or } \\
\text { non-calcific acquired aortic stenosis, } \\
\text { uni- or bicuspid aortic valve. } \\
\text {-Anatomy not appropriate for } \\
\text { transfemoral TAVR due to degree or } \\
\text { eccentricity of calcification or } \\
\text { tortuosity of aorto- and iliac-femoral } \\
\text { arteries. -Pre-existing prosthetic heart } \\
\text { valve in aortic or mitral position. } \\
\text {-Emergency procedures, cardiogenic } \\
\text { shock (vasopressor dependence, } \\
\text { mechanical hemodynamic support), } \\
\text { or severely reduced left ventricular } \\
\text { ejection fraction (<20\%). } \\
\text {-Concomitant planned procedure } \\
\text { except for percutaneous coronary } \\
\text { intervention. -Stroke or myocardial } \\
\text { infarction (except type 2) in prior } 30 \\
\text { days. -Planned non-cardiac surgery } \\
\text { within } 30 \text { days after TAVR. -Severe } \\
\text { coagulation conditions, inability to } \\
\text { tolerate anticoagulation/antiplatelet } \\
\text { therapy. -Evidence of intra-cardiac } \\
\text { mass, thrombus or vegetation. } \\
\text {-Active bacterial endocarditis or other } \\
\text { active infection. -Hypertrophic } \\
\text { cardiomyopathy with or without } \\
\text { obstruction. -Contraindication to } \\
\text { contrast media or allergy to nitinol. } \\
\text {-Participation in another trial leading } \\
\text { to deviations in the preparation and } \\
\text { conduction of the intervention or the } \\
\text { post-implantation management. }\end{array}$ & $\begin{array}{l}\text { The heart team or an } \\
\text { STS-PROM score }>10 \% \text { or a } \\
\text { Logistic EuroSCORE }>20 \% \text {. } \\
\text { Heart team agrees on eligibility } \\
\text { for participation. }\end{array}$ & $\begin{array}{l}\text { Patients were randomly } \\
\text { assigned in a 1:1 ratio to } \\
\text { undergo TAVI with either the } \\
\text { ACURATE neo or the SAPIEN } 3 \\
\text { system. }\end{array}$ \\
\hline
\end{tabular}


Table A3. Cont.

\begin{tabular}{|c|c|c|c|c|}
\hline Study [ref] & Inclusion criteria & Exclusion criteria & $\begin{array}{l}\text { Selection criteria for the } \\
\text { procedure }\end{array}$ & Selection criteria for the valve \\
\hline Mauri V et al. 2017 [18] & $\begin{array}{l}\text { Inclusion criteria were small } \\
\text { annular dimension defined as } \\
\text { an annulus area }<400 \mathrm{~mm}^{2} \text { and } \\
\text { transfemoral TAVI with either } \\
\text { an ACURATE neo size } S \text { or an } \\
\text { Edwards SAPIEN } 3 \text { size } 23 \mathrm{~mm} \text {. }\end{array}$ & Not reported. & $\begin{array}{l}\text { Eligibility of the individual } \\
\text { candidate for TAVI had been } \\
\text { decided within the local } \\
\text { institutional heart team. }\end{array}$ & $\begin{array}{l}\text { Prosthesis selection was at the } \\
\text { discretion of the operating } \\
\text { physicians at each center. }\end{array}$ \\
\hline Schaefer A et al. 2017 [19] & $\begin{array}{l}\text { A consecutive series of } 104 \\
\text { patients received transfemoral } \\
\text { TAVI using the ACURATE neo } \\
\text { for treatment of severe } \\
\text { symptomatic calcified aortic } \\
\text { stenosis (study group) between } \\
2012 \text { and 2016. For comparative } \\
\text { assessment, a matched control } \\
\text { group of } 104 \text { patients treated by } \\
\text { transfemoral TAVI using the } \\
\text { Edwards SAPIEN } 3 \text { during the } \\
\text { same time frame (2014 to 2016) } \\
\text { was retrieved from dedicated } \\
\text { hospital database containing a } \\
\text { total of } 1326 \text { TAVI patients ( } 210 \\
\text { SAPIEN } 3 \text { patients). }\end{array}$ & $\begin{array}{l}\text { Patients unsuitable for a retrograde } \\
\text { transfemoral approach and all } \\
\text { valve-in-valve procedures were } \\
\text { excluded from analysis. }\end{array}$ & $\begin{array}{c}\text { Allocation of patients to TAVI } \\
\text { followed current international } \\
\text { recommendations after } \\
\text { consensus of the local dedicated } \\
\text { heart team. }\end{array}$ & Not reported. \\
\hline
\end{tabular}


Table A4. Patients' baseline characteristics.

\begin{tabular}{|c|c|c|c|c|c|c|c|c|c|c|c|c|c|c|c|c|c|}
\hline Study [ref] & Intervention & $\begin{array}{l}\text { HT } \\
(\%)\end{array}$ & $\begin{array}{l}\text { DM } \\
(\%)\end{array}$ & $\begin{array}{l}\text { PVD } \\
(\%)\end{array}$ & $\begin{array}{l}\text { CKI } \\
(\%)\end{array}$ & $\begin{array}{c}\text { COPD } \\
(\%)\end{array}$ & $\begin{array}{c}\text { PM/ICD } \\
(\%)\end{array}$ & $\begin{array}{l}\mathrm{AF} \\
(\%)\end{array}$ & $\begin{array}{l}\text { CAD } \\
(\%)\end{array}$ & $\begin{array}{c}\text { MI } \\
\text { history } \\
(\%)\end{array}$ & $\begin{array}{c}\text { Stroke } \\
\text { history } \\
(\%)\end{array}$ & $\begin{array}{l}\text { Heart } \\
\text { surgery } \\
\text { history } \\
(\%)\end{array}$ & $\begin{array}{l}\text { NYHA } \\
\text { III/IV } \\
(\%)\end{array}$ & LVEF (\%) & $\begin{array}{l}\text { Mean } \\
\text { aortic } \\
\text { gradient } \\
(\mathrm{mmHg})\end{array}$ & $\begin{array}{c}\text { Aortic } \\
\text { valve area } \\
\left(\mathrm{cm}^{2}\right)\end{array}$ & $\begin{array}{c}\text { Aortic } \\
\text { annulus } \\
\text { diameter } \\
(\mathrm{mm})\end{array}$ \\
\hline \multirow{2}{*}{$\begin{array}{c}\text { Barth S et al. } \\
2019 \text { [15] }\end{array}$} & $\begin{array}{l}\text { ACURATE } \\
\text { neo }\end{array}$ & 93.3 & 36.8 & NR & 2.7 & 15.8 & NR & 38.0 & NR & NR & 14.0 & 14.9 & 79.0 & $53.0 \pm 13.0$ & $44.0 \pm 15.0$ & $0.68 \pm 0.18$ & $21.0 \pm 2.0$ \\
\hline & SAPIEN 3 & 93.0 & 35.0 & NR & 2.7 & 14.9 & NR & 38.7 & NR & NR & 14.6 & 14.6 & 78.1 & $54.0 \pm 15.0$ & $45.0 \pm 14.0$ & $0.67 \pm 0.17$ & $21.0 \pm 3.0$ \\
\hline \multirow{2}{*}{$\begin{array}{l}\text { Costa et al. } \\
2019 \text { [16] }\end{array}$} & $\begin{array}{c}\text { ACURATE } \\
\text { neo }\end{array}$ & 89.6 & 18.8 & 6.3 & 4.2 & 20.8 & NR & 12.5 & NR & 14.6 & 2.1 & 6.3 & NR & $54.5 \pm 9.7$ & $51.3 \pm 14.5$ & NR & NR \\
\hline & SAPIEN 3 & 89.6 & 27.1 & 4.2 & 2.1 & 14.6 & NR & 12.5 & NR & 14.6 & 4.2 & 2.1 & NR & $56.1 \pm 9.7$ & $51.3 \pm 17.2$ & NR & NR \\
\hline \multirow{2}{*}{$\begin{array}{l}\text { Husser O et } \\
\text { al. } 2017 \text { [17] }\end{array}$} & $\begin{array}{c}\text { ACURATE } \\
\text { neo }\end{array}$ & NR & 33.1 & 10.6 & 2.3 & 13.5 & 9.0 & 24.8 & 61.1 & 10.0 & 13.8 & 10.6 & 82.3 & NR & $45.0 \pm 15.0$ & NR & NR \\
\hline & SAPIEN 3 & NR & 32.3 & 11.3 & 1.9 & 17.8 & 10.0 & 26.2 & 62.7 & 10.1 & 12.5 & 8.7 & 78.6 & NR & $44.0 \pm 16.0$ & NR & NR \\
\hline \multirow[t]{2}{*}{$\begin{array}{l}\text { Lanz J et al. } \\
2019 \text { [14] }\end{array}$} & $\begin{array}{l}\text { ACURATE } \\
\text { neo }\end{array}$ & 92.0 & 29.0 & 12.0 & 4.0 & 9.0 & 12.0 & 36.0 & 59.0 & 10.0 & 13.0 & 9.0 & 77.0 & $56.4 \pm 11.1$ & $42.9 \pm 17.2$ & $0.7 \pm 0.2$ & $23.6 \pm 1.6$ \\
\hline & $\begin{array}{l}\text { ACURATE } \\
\text { neo }\end{array}$ & 91.0 & 32.0 & 11.0 & 5.0 & 12.0 & 10.0 & 37.0 & 60.0 & 13.0 & 13.0 & 9.0 & 73.0 & $57.1 \pm 10.7$ & $41.5 \pm 15.1$ & $0.7 \pm 0.2$ & $23.7 \pm 1.6$ \\
\hline \multirow{2}{*}{$\begin{array}{c}\text { Mauri V et al. } \\
2017 \text { [18] }\end{array}$} & SAPIEN 3 & NR & NR & NR & NR & NR & NR & NR & NR & NR & NR & NR & NR & $59.0 \pm 8.0$ & $46.0 \pm 16.0$ & NR & NR \\
\hline & $\begin{array}{l}\text { ACURATE } \\
\text { neo }\end{array}$ & NR & NR & NR & NR & NR & NR & NR & NR & NR & NR & NR & NR & $59.0 \pm 10.0$ & $47.0 \pm 16.0$ & NR & NR \\
\hline \multirow{2}{*}{$\begin{array}{l}\text { Schaefer A et } \\
\text { al. } 2017 \text { [19] }\end{array}$} & SAPIEN 3 & 85.6 & 27.9 & 16.3 & NR & 17.3 & NR & 34.6 & 59.6 & NR & 14.4 & 9.6 & 86.5 & NR & $35.9 \pm 16.6$ & $0.8 \pm 0.2$ & $24.5 \pm 2.5$ \\
\hline & $\begin{array}{c}\text { ACURATE } \\
\text { neo }\end{array}$ & 93.3 & 26.0 & 13.5 & NR & 20.2 & NR & 32.7 & 57.7 & NR & 11.5 & 5.8 & 88.5 & NR & $37.6 \pm 16.7$ & $0.8 \pm 0.2$ & $25.3 \pm 2.6$ \\
\hline
\end{tabular}

HT, hypertension; DM, diabetes mellitus; PVD, peripheral vascular disease; $\mathrm{CKI}$, chronic kidney injury; COPD, chronic obstructive pulmonary disease; PM/ICD, pacemaker/implantable cardioverter-defibrillator; $\mathrm{AF}$, atrial fibrillation; $\mathrm{CAD}$, coronary artery disease; MI, myocardial infarction; LVEF, left ventricle ejection fraction; NR, not reported. In bold are highlighted the variables that differed significantly. 
Table A5. Procedural characteristics.

\begin{tabular}{|c|c|c|c|c|c|c|c|c|c|}
\hline Study [ref] & Intervention & $\begin{array}{c}\text { Anesthesia } \\
(\%)\end{array}$ & $\begin{array}{c}\text { Access Site } \\
(\%)\end{array}$ & $\begin{array}{c}\text { Valve sizes } \\
\text { Implanted (\%), } \\
\text { (Mean } \pm \text { SD) }\end{array}$ & $\begin{array}{l}\text { Pre-Dilatation } \\
(\%)\end{array}$ & $\begin{array}{l}\text { Post-Dilatation } \\
(\%)\end{array}$ & $\begin{array}{c}\text { Contrast } \\
\text { Volume }(\mathrm{mL})\end{array}$ & $\begin{array}{l}\text { Fluoroscopy } \\
\text { Time (min) }\end{array}$ & $\begin{array}{c}\text { Procedure } \\
\text { Duration } \\
\text { (min) }\end{array}$ \\
\hline \multirow[t]{2}{*}{$\begin{array}{c}\text { Barth S et al. } \\
2019 \text { [15] }\end{array}$} & $\begin{array}{c}\text { ACURATE } \\
\text { neo }\end{array}$ & $\begin{array}{c}\text { general 96.0, } \\
\text { conscious } \\
\text { sedation } 4.0\end{array}$ & $\begin{array}{c}\text { femoral } 74.5 \\
\text { apical } 25.5\end{array}$ & $\begin{array}{c}\text { S NR } \\
\text { M NR } \\
\text { L NR } \\
(25.0 \pm 2.0)\end{array}$ & 97.6 & 40.4 & $128 \pm 54$ & $9.2 \pm 4.4$ & $62.0 \pm 24.0$ \\
\hline & SAPIEN 3 & $\begin{array}{c}\text { general 96.4, } \\
\text { conscious } \\
\text { sedation } 3.6\end{array}$ & $\begin{array}{c}\text { femoral } 75.7 \\
\text { apical } 24.3\end{array}$ & $\begin{array}{l}23 \mathrm{~mm} \mathrm{NR} \\
26 \mathrm{~mm} \mathrm{NR} \\
29 \mathrm{~mm} \mathrm{NR} \\
(25.0 \pm 2.0)\end{array}$ & 52.1 & 11.6 & $106 \pm 43$ & $8.5 \pm 4.9$ & $59.0 \pm 26.0$ \\
\hline \multirow[t]{2}{*}{$\begin{array}{l}\text { Costa et al. } \\
2019[16]\end{array}$} & $\begin{array}{l}\text { ACURATE } \\
\text { neo }\end{array}$ & NR & femoral 100 & NR & NR & NR & NR & NR & NR \\
\hline & SAPIEN 3 & & femoral 100 & NR & NR & NR & NR & NR & NR \\
\hline \multirow[t]{2}{*}{$\begin{array}{l}\text { Husser O et al. } \\
2017 \text { [17] }\end{array}$} & $\begin{array}{l}\text { ACURATE } \\
\text { neo }\end{array}$ & $\begin{array}{c}\text { general } 52.7 \\
\text { conscious } \\
\text { sedation } 47.3\end{array}$ & femoral 100 & $\begin{array}{l}\text { S } 30.9 \\
\text { M } 40.2 \\
\text { L } 28.9\end{array}$ & 95.8 & 42.1 & $115.0 \pm 54.0$ & $10.0 \pm 6.0$ & $55.0 \pm 30.0$ \\
\hline & SAPIEN 3 & $\begin{array}{c}\text { general 54.0, } \\
\text { conscious } \\
\text { sedation } 46.0\end{array}$ & femoral 100 & $\begin{array}{l}23 \mathrm{~mm} 43.9 \\
26 \mathrm{~mm} 41.6 \\
29 \mathrm{~mm} 14.5 \\
\end{array}$ & 74.3 & 23.8 & $104.0 \pm 53.0$ & $11.0 \pm 5.9$ & $54.0 \pm 24.0$ \\
\hline \multirow[t]{2}{*}{$\begin{array}{l}\text { Lanz J et al. } \\
2019[14]\end{array}$} & $\begin{array}{c}\text { ACURATE } \\
\text { neo }\end{array}$ & $\begin{array}{c}\text { general 25.0 } \\
\text { conscious } \\
\text { sedation } 75.0\end{array}$ & $\begin{array}{c}\text { femoral 99.0, } \\
\text { other 1.0 }\end{array}$ & $\begin{array}{l}\text { S } 20.0 \\
\text { M } 43.0 \\
\text { L } 34.0\end{array}$ & 88.0 & 52.0 & $136.0 \pm 55.6$ & NR & $53.2 \pm 26.5$ \\
\hline & SAPIEN 3 & $\begin{array}{c}\text { general 23.0, } \\
\text { conscious } \\
\text { sedation } 77.0\end{array}$ & $\begin{array}{c}\text { femoral 99.0 } \\
\text { other 1.0 }\end{array}$ & $\begin{array}{c}23 \mathrm{~mm} 39.0 \\
26 \mathrm{~mm} 55.0 \\
29 \mathrm{~mm} 5.0\end{array}$ & 23.0 & 48.0 & $110 \pm 45.9$ & NR & $46.0 \pm 25.9$ \\
\hline \multirow{2}{*}{$\begin{array}{l}\text { Mauri V et al. } \\
2017 \text { [18] }\end{array}$} & $\begin{array}{l}\text { ACURATE } \\
\text { neo }\end{array}$ & general 100.0 & femoral 100 & S 100.0 & 94.6 & 31.5 & NR & NR & NR \\
\hline & SAPIEN 3 & & femoral 100 & $23 \mathrm{~mm} 100.0$ & 31.5 & 6.5 & NR & NR & NR \\
\hline \multirow[t]{2}{*}{$\begin{array}{l}\text { Schaefer A et } \\
\text { al. } 2017 \text { [19] }\end{array}$} & $\begin{array}{c}\text { ACURATE } \\
\text { neo }\end{array}$ & $\begin{array}{c}\text { conscious } \\
\text { sedation } \\
47.1 \% \\
\text { general } 52.9 \%\end{array}$ & femoral 100 & $\begin{array}{l}\text { S } 35.6 \\
\text { M } 38.5 \\
\text { L } 25.9\end{array}$ & 90.3 & 47.6 & $162.6 \pm 70.3$ & $19.3 \pm 9.4$ & $94.0 \pm 46.9$ \\
\hline & SAPIEN 3 & $\begin{array}{c}\text { conscious } \\
\text { sedation } \\
34.6 \% \\
\text { general } 65.4 \%\end{array}$ & femoral 100 & $\begin{array}{l}23 \mathrm{~mm} 40.4 \\
26 \mathrm{~mm} 49.0 \\
29 \mathrm{~mm} 10.6\end{array}$ & 53.8 & 20.2 & $154.8 \pm 73.0$ & $19.4 \pm 9.1$ & $94.8 \pm 38.0$ \\
\hline
\end{tabular}


Table A6. VARC-2 derived permanent pacemaker implantation criteria quality appraisal.

\begin{tabular}{cccc}
\hline Study [ref] & $\begin{array}{c}\text { Presence of Pacemaker } \\
\text { at Baseline Reported }\end{array}$ & $\begin{array}{c}\text { Precision of the } \\
\text { Indication Reported }\end{array}$ & $\begin{array}{c}\text { Days Post TAVR for PPI } \\
\text { Reported }\end{array}$ \\
\hline Barth S et al. 2019 [15] & No & no & In-hospital \\
\hline Costa et al. 2019 [16] & Yes & no & In-hospital and 30 days \\
\hline Husser O et al. 2017 [17] & Yes & no & 30 days \\
\hline Lanz J et al. 2019 [14] & Yes & no & 30 days \\
\hline Mauri V et al 2017 [18] & No & $\begin{array}{c}\text { Atrioventricular block } \\
\text { Grade 3 or rapid } \\
\text { progressive left bundle } \\
\text { branch block }\end{array}$ & In-hospital \\
\hline Schaefer A et al. 2017 & No & &
\end{tabular}

TAVR, transcatheter aortic valve replacement; PPI, permanent pacemaker implantation; NA, not available.

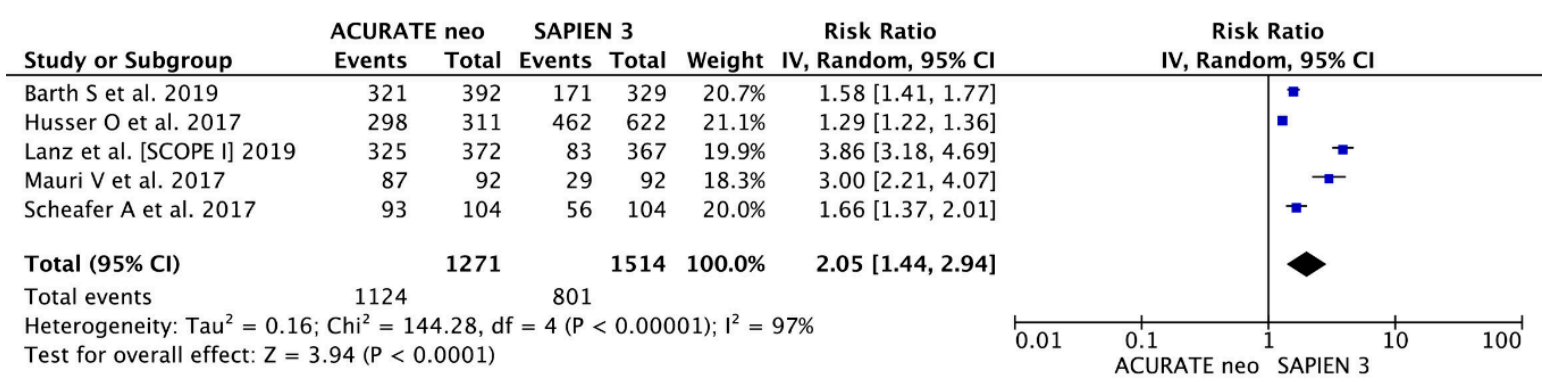

Figure A1. Procedural outcomes. Individual and summary risk ratios with corresponding 95\% confidence intervals for the comparison of ACURATE neo vs. SAPIEN 3 in the analysis of predilatation.

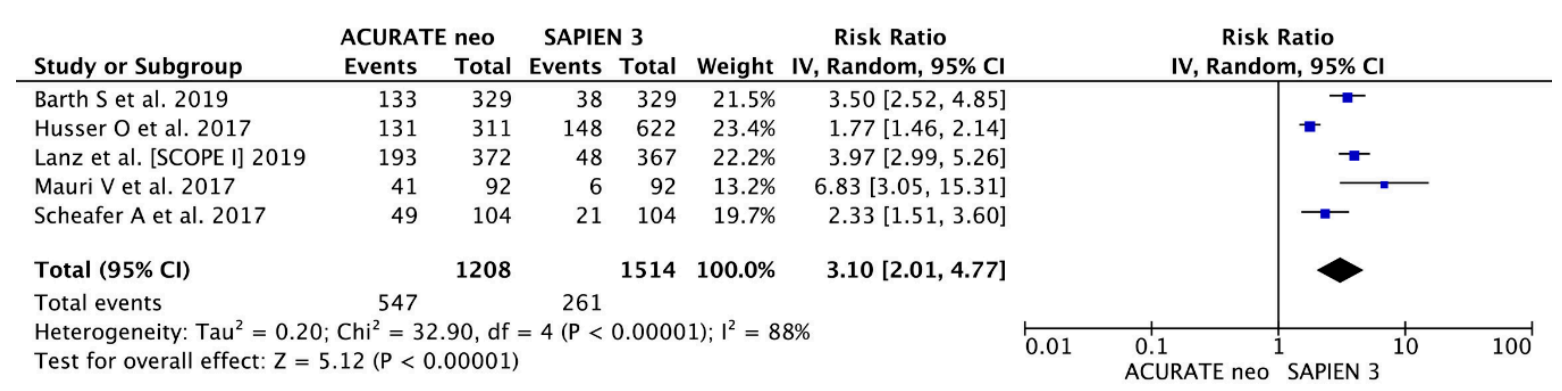

Figure A2. Procedural outcomes. Individual and summary risk ratios with corresponding 95\% confidence intervals for the comparison of ACURATE neo vs. SAPIEN 3 in the analysis of postdilatation.

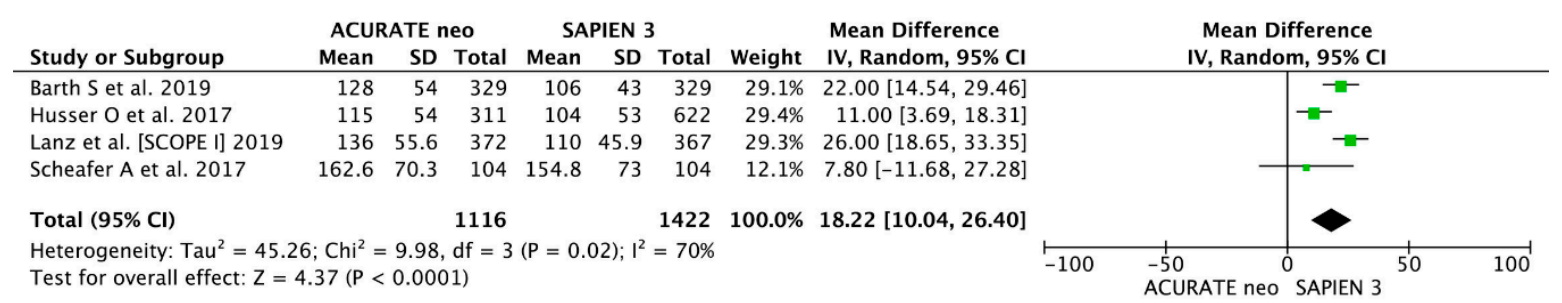

Figure A3. Procedural outcomes. Detailed analysis of individual weighted mean differences (MDs) with corresponding $95 \%$ CIs on contrast volume used for the comparison of ACURATE neo vs. SAPIEN 3. 


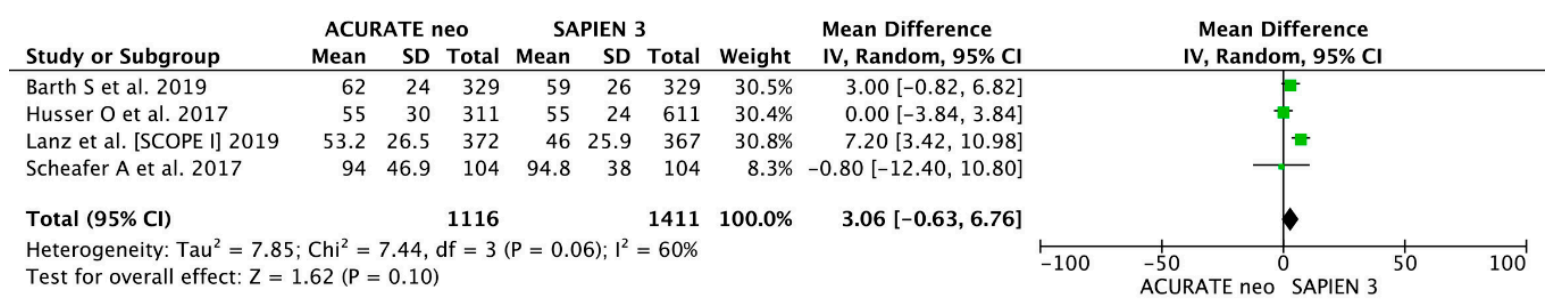

Figure A4. Procedural outcomes. Detailed analysis of individual weighted mean differences (MDs) with corresponding 95\% CIs on procedure duration for the comparison of ACURATE neo vs. SAPIEN 3.

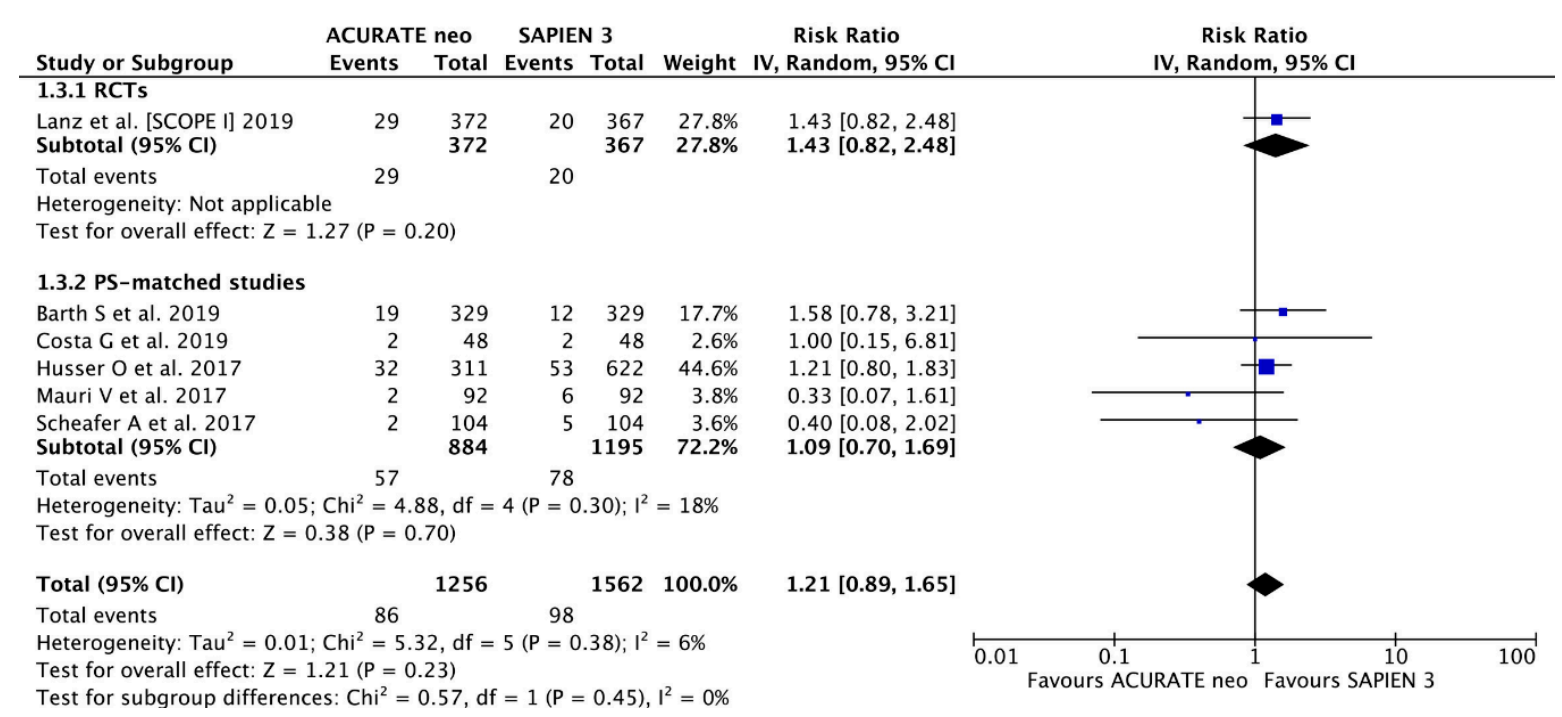

Figure A5. Clinical outcomes. Individual and summary risk ratios with corresponding 95\% confidence intervals for the comparison of ACURATE neo and SAPIEN 3 in the analysis of major vascular complications.

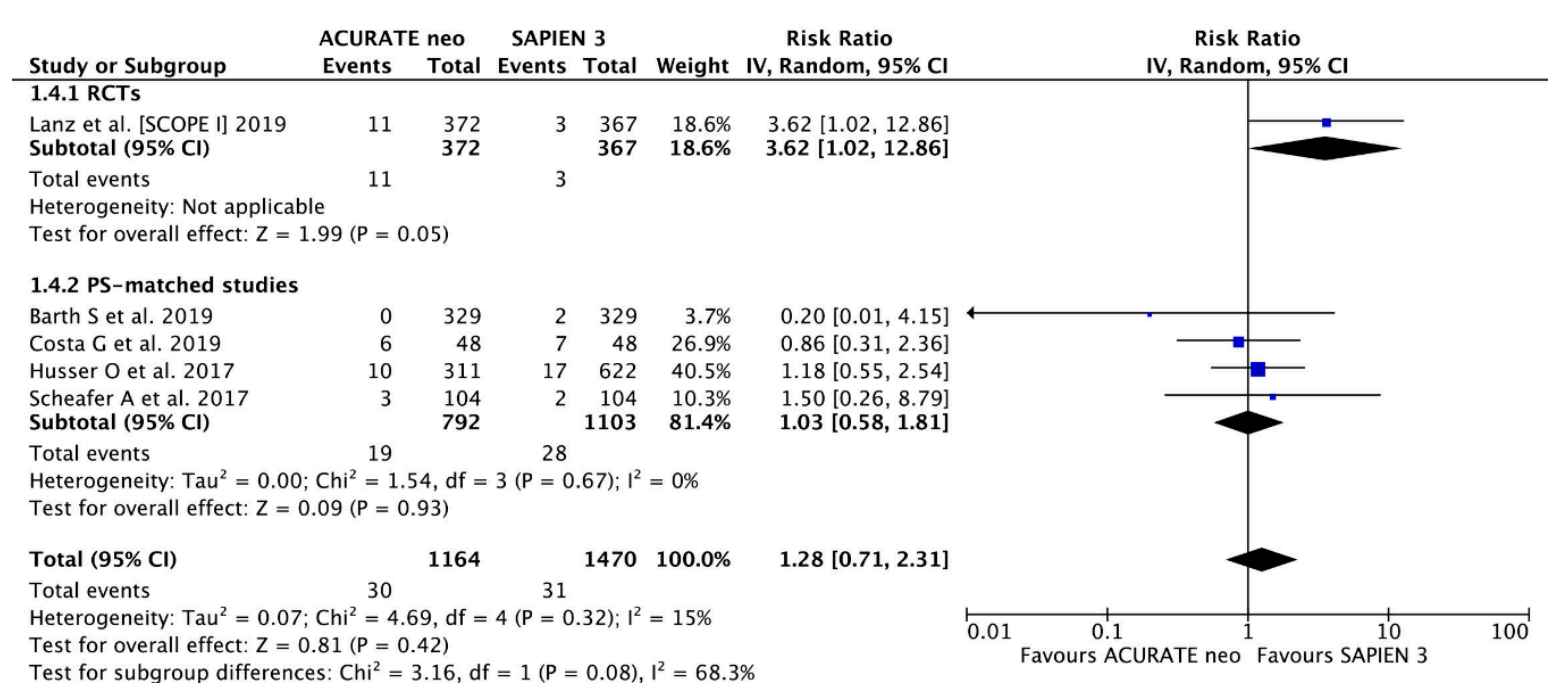

Figure A6. Clinical outcomes. Individual and summary risk ratios with corresponding 95\% confidence intervals for the comparison of ACURATE neo and SAPIEN 3 in the analysis of acute kidney injury. 


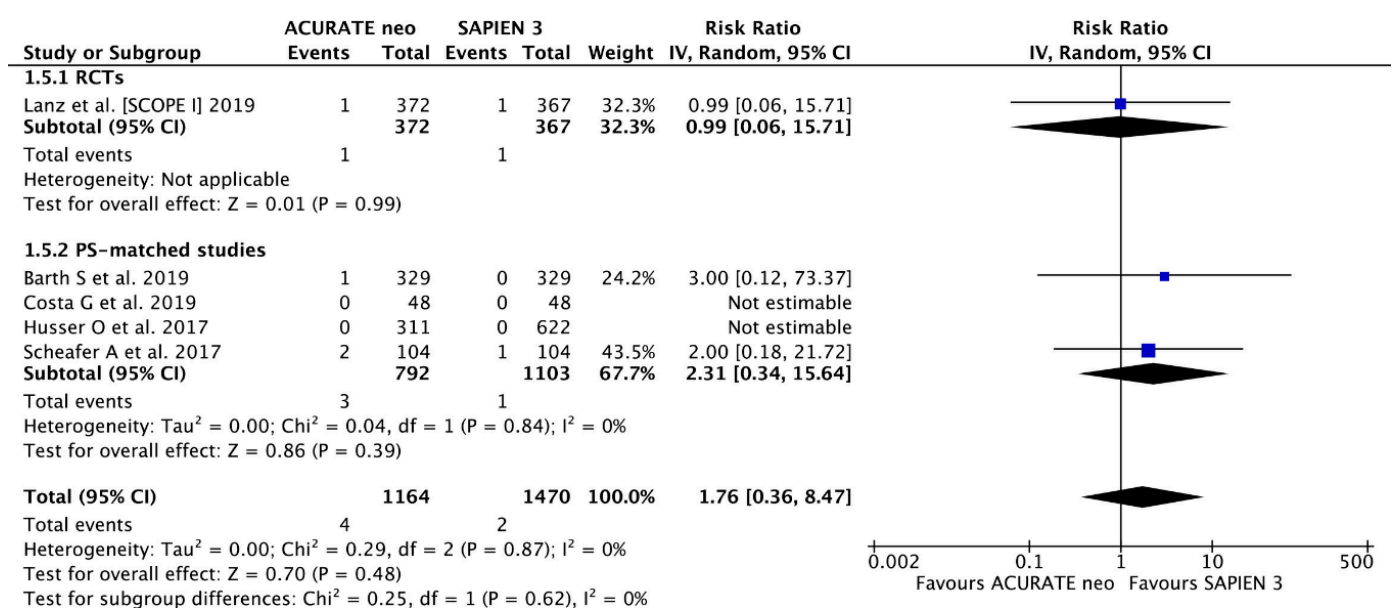

Figure A7. Clinical outcomes. Individual and summary risk ratios with corresponding $95 \%$ confidence intervals for the comparison of ACURATE neo and SAPIEN 3 in the analysis of periprocedural myocardial infarction.

\begin{tabular}{|c|c|c|c|c|c|c|c|}
\hline Study or Subgroup & $\begin{array}{l}\text { ACURAT } \\
\text { Events }\end{array}$ & $\begin{array}{l}\text { neo } \\
\text { Total }\end{array}$ & $\begin{array}{l}\text { SAPIE } \\
\text { Events }\end{array}$ & $\begin{array}{l}\text { N } 3 \\
\text { Total }\end{array}$ & Weight & $\begin{array}{l}\text { Risk Difference } \\
\text { IV, Random, } 95 \% \mathrm{Cl}\end{array}$ & $\begin{array}{c}\text { Risk Difference } \\
\text { IV, Random, } 95 \% \mathrm{CI}\end{array}$ \\
\hline \multicolumn{8}{|l|}{ 1.5.1 RCTs } \\
\hline $\begin{array}{l}\text { Lanz et al. [SCOPE I] } 2019 \\
\text { Subtotal }(95 \% \mathrm{CI})\end{array}$ & 1 & $\begin{array}{l}372 \\
372\end{array}$ & 1 & $\begin{array}{l}367 \\
367\end{array}$ & $\begin{array}{l}24.0 \% \\
24.0 \%\end{array}$ & $\begin{array}{l}-0.00[-0.01,0.01] \\
-0.00[-0.01,0.01]\end{array}$ & \\
\hline \multicolumn{8}{|c|}{$\begin{array}{l}\text { Heterogeneity: Not applicable } \\
\text { Test for overall effect: } Z=0.01(P=0.99)\end{array}$} \\
\hline \multicolumn{8}{|l|}{ 1.5.2 PS-matched studies } \\
\hline Barth S et al. 2019 & 1 & 329 & 0 & 329 & $19.2 \%$ & $0.00[-0.01,0.01]$ & - \\
\hline $\begin{array}{l}\text { Costa G et al. } 2019 \\
\text { Husser O et al. } 2017\end{array}$ & $\begin{array}{l}0 \\
0\end{array}$ & $\begin{array}{r}48 \\
311\end{array}$ & $\begin{array}{l}0 \\
0\end{array}$ & $\begin{array}{r}48 \\
622\end{array}$ & $\begin{array}{r}0.9 \% \\
54.7 \%\end{array}$ & $\begin{array}{l}0.00[-0.04,0.04] \\
0.00[-0.00,0.00]\end{array}$ & \\
\hline $\begin{array}{l}\text { Scheafer A et al. } 2017 \\
\text { Subtotal }(95 \% \mathrm{Cl})\end{array}$ & 2 & $\begin{array}{l}104 \\
792\end{array}$ & 1 & $\begin{array}{r}104 \\
1103\end{array}$ & $\begin{array}{r}1.3 \% \\
76.0 \%\end{array}$ & $\begin{array}{l}0.01[-0.02,0.04] \\
0.00[-0.00,0.01]\end{array}$ & \\
\hline \multicolumn{8}{|c|}{$\begin{array}{l}\text { Total events } \\
\text { Heterogeneity: } \text { Tau }^{2}=0.00 ; \mathrm{Chi}^{2}=0.66, \mathrm{df}=3(\mathrm{P}=0.88) ; \mathrm{I}^{2}=0 \% \\
\text { Test for overall effect: } \mathrm{Z}=0.43(\mathrm{P}=0.67)\end{array}$} \\
\hline Total $(95 \% \mathrm{Cl})$ & & 1164 & & 1470 & $100.0 \%$ & $0.00[-0.00,0.00]$ & \\
\hline Total events & 4 & & 2 & & & & \\
\hline \multicolumn{7}{|c|}{$\begin{array}{l}\text { Heterogeneity: } \mathrm{Tau}^{2}=0.00 ; \mathrm{Chi}^{2}=0.71, \mathrm{df}=4(\mathrm{P}=0.95) ; \mathrm{I}^{2}=0 \% \\
\text { Test for overall effect: } \mathrm{Z}=0.37(\mathrm{P}=0.71) \\
\text { Test for subgroup differences: } \mathrm{Chi}^{2}=0.05, \mathrm{df}=1(\mathrm{P}=0.83), \mathrm{I}^{2}=0 \%\end{array}$} & 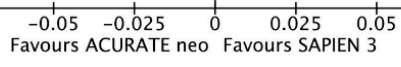 \\
\hline
\end{tabular}

Figure A8. Clinical outcomes. Individual and summary risk ratios with corresponding $95 \%$ confidence intervals for the comparison of ACURATE neo and SAPIEN 3 in the analysis of periprocedural myocardial infarction taking into account "0 events".

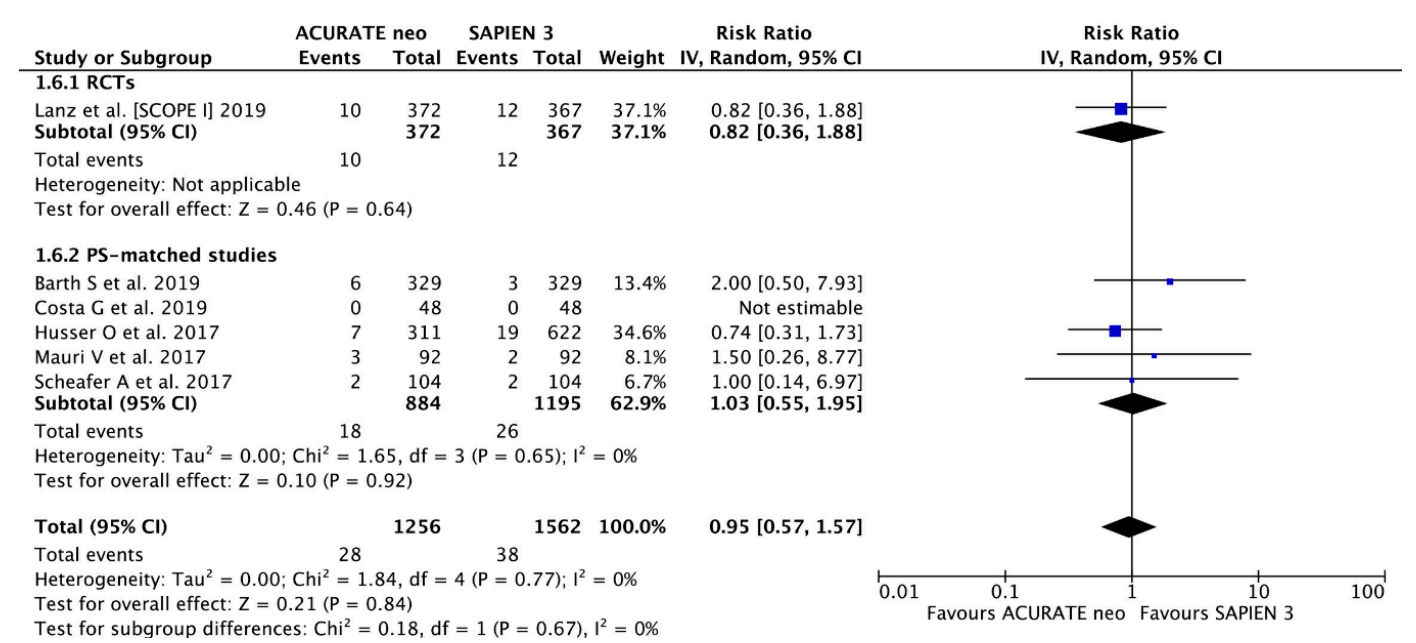

Figure A9. Clinical outcomes. Individual and summary risk ratios with corresponding 95\% confidence intervals for the comparison of ACURATE neo and SAPIEN 3 in the analysis of stroke. 


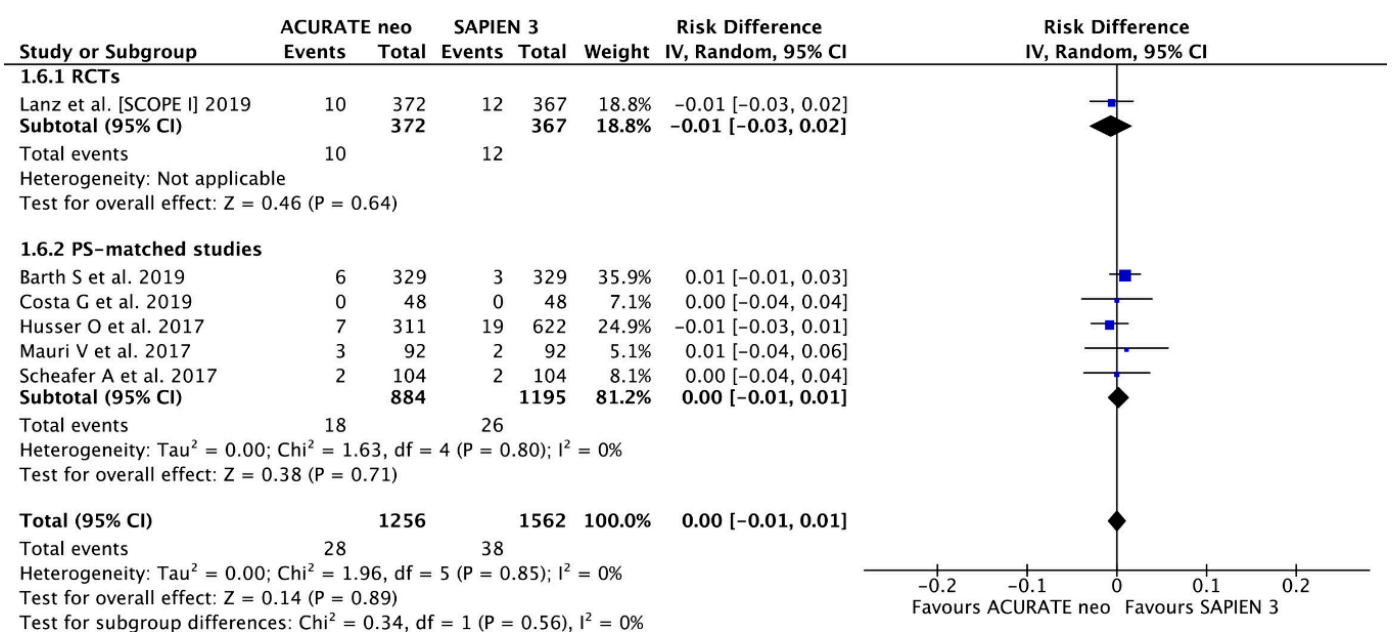

Figure A10. Clinical outcomes. Individual and summary risk ratios with corresponding 95\% confidence intervals for the comparison of ACURATE neo and SAPIEN 3 in the analysis of stroke taking into account " 0 events".

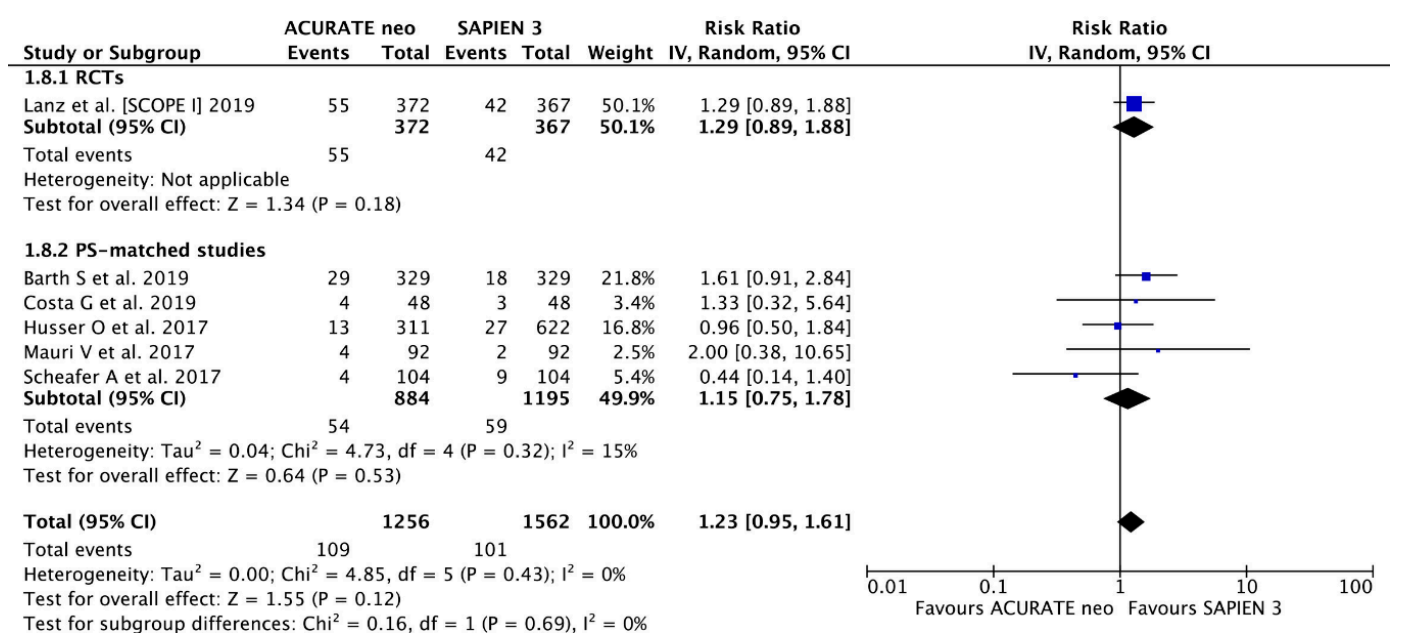

Figure A11. Clinical outcomes. Individual and summary risk ratios with corresponding 95\% confidence intervals for the comparison of ACURATE neo and SAPIEN 3 in the analysis serious bleeding events.

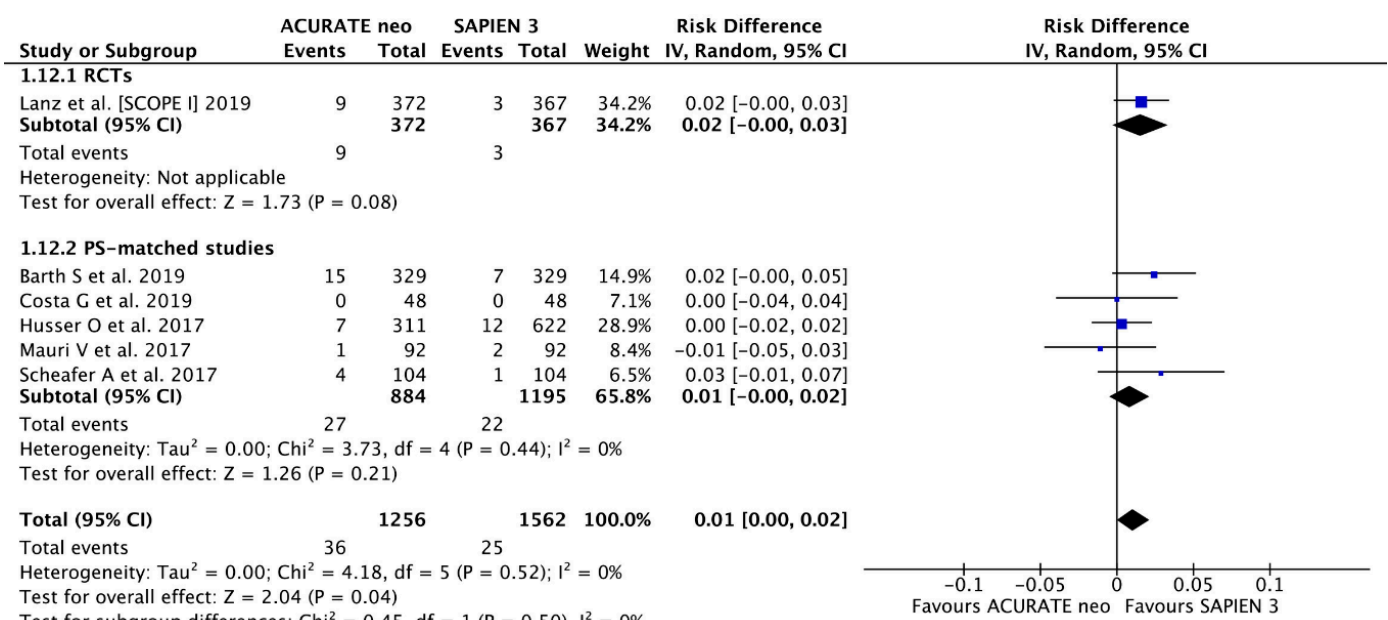

Figure A12. Clinical outcomes. Individual and summary risk ratios with corresponding $95 \%$ confidence intervals for the comparison of ACURATE neo and SAPIEN 3 in the analysis of 30-day all-cause mortality taking into account " 0 events". 


\section{References}

1. Cribier, A.; Eltchaninoff, H.; Bash, A.; Borenstein, N.; Tron, C.; Bauer, F.; Derumeaux, G.; Anselme, F.; Laborde, F.; Leon, M.B. Percutaneous transcatheter implantation of an aortic valve prosthesis for calcific aortic stenosis: First human case description. Circulation 2002, 106, 3006-3008. [CrossRef]

2. Smith, C.R.; Leon, M.B.; Mack, M.J.; Miller, D.C.; Moses, J.W.; Svensson, L.G.; Tuzcu, E.M.; Webb, J.G.; Fontana, G.P.; Makkar, R.R.; et al. Transcatheter versus surgical aortic-valve replacement in high-risk patients. N. Engl. J. Med. 2011, 364, 2187-2198. [CrossRef] [PubMed]

3. Adams, D.H.; Popma, J.J.; Reardon, M.J.; Yakubov, S.J.; Coselli, J.S.; Deeb, G.M.; Gleason, T.G.; Buchbinder, M.; Hermiller, J., Jr.; Kleiman, N.S.; et al. Transcatheter aortic-valve replacement with a self-expanding prosthesis. N. Engl. J. Med. 2014, 370, 1790-1798. [CrossRef] [PubMed]

4. Webb, J.G.; Pasupati, S.; Humphries, K.; Thompson, C.; Altwegg, L.; Moss, R.; Sinhal, A.; Carere, R.G.; Munt, B.; Ricci, D.; et al. Percutaneous transarterial aortic valve replacement in selected high-risk patients with aortic stenosis. Circulation 2007, 116, 755-763. [CrossRef]

5. Leon, M.B.; Smith, C.R.; Mack, M.; Miller, D.C.; Moses, J.W.; Svensson, L.G.; Tuzcu, E.M.; Webb, J.G.; Fontana, G.P.; Makkar, R.R.; et al. Transcatheter aortic-valve implantation for aortic stenosis in patients who cannot undergo surgery. N. Engl. J. Med. 2010, 363, 1597-1607. [CrossRef]

6. Thourani, V.H.; Kodali, S.; Makkar, R.R.; Herrmann, H.C.; Williams, M.; Babaliaros, V.; Smalling, R.; Lim, S.; Malaisrie, S.C.; Kapadia, S.; et al. Transcatheter aortic valve replacement versus surgical valve replacement in intermediate-risk patients: A propensity score analysis. Lancet 2016, 387, 2218-2225. [CrossRef]

7. Leon, M.B.; Smith, C.R.; Mack, M.J.; Makkar, R.R.; Svensson, L.G.; Kodali, S.K.; Thourani, V.H.; Tuzcu, E.M.; Miller, D.C.; Herrmann, H.C.; et al. Transcatheter or Surgical Aortic-Valve Replacement in Intermediate-Risk Patients. N. Engl. J. Med. 2016, 374, 1609-1620. [CrossRef]

8. Reardon, M.J.; Van Mieghem, N.M.; Popma, J.J.; Kleiman, N.S.; Sondergaard, L.; Mumtaz, M.; Adams, D.H.; Deeb, G.M.; Maini, B.; Gada, H.; et al. Surgical or Transcatheter Aortic-Valve Replacement in Intermediate-Risk Patients. N. Engl. J. Med. 2017, 376, 1321-1331. [CrossRef]

9. Mack, M.J.; Leon, M.B.; Thourani, V.H.; Makkar, R.; Kodali, S.K.; Russo, M.; Kapadia, S.R.; Malaisrie, S.C.; Cohen, D.J.; Pibarot, P.; et al. Transcatheter Aortic-Valve Replacement with a Balloon-Expandable Valve in Low-Risk Patients. N. Engl. J. Med. 2019, 380, 1695-1705. [CrossRef]

10. Nishimura, R.A.; Otto, C.M.; Bonow, R.O.; Carabello, B.A.; Erwin, J.P., 3rd; Fleisher, L.A.; Jneid, H.; Mack, M.J.; McLeod, C.J.; O'Gara, P.T.; et al. 2017 AHA/ACC Focused Update of the 2014 AHA/ACC Guideline for the Management of Patients With Valvular Heart Disease: A Report of the American College of Cardiology/American Heart Association Task Force on Clinical Practice Guidelines. Circulation 2017, 135, e1159-e1195. [CrossRef]

11. Van Belle, E.; Juthier, F.; Susen, S.; Vincentelli, A.; Dallongeville, J.; Iung, B.; Eltchaninoff, H.; Laskar, M.; Leprince, P.; Lievre, M.; et al. Response to letter regarding article, "postprocedural aortic regurgitation in balloon-expandable and self-expandable transcatheter aortic valve replacement procedures: Analysis of predictors and impact on long-term mortality: Insights from the FRANCE2 registry". Circulation 2015, 131, e16-e17. [CrossRef]

12. Kodali, S.K.; Williams, M.R.; Smith, C.R.; Svensson, L.G.; Webb, J.G.; Makkar, R.R.; Fontana, G.P.; Dewey, T.M.; Thourani, V.H.; Pichard, A.D.; et al. Two-year outcomes after transcatheter or surgical aortic-valve replacement. N. Engl. J. Med. 2012, 366, 1686-1695. [CrossRef]

13. Jones, B.M.; Tuzcu, E.M.; Krishnaswamy, A.; Popovic, Z.; Mick, S.; Roselli, E.E.; Gul, S.; Devgun, J.; Mistry, S.; Jaber, W.A.; et al. Prognostic significance of mild aortic regurgitation in predicting mortality after transcatheter aortic valve replacement. J. Thorac. Cardiovasc. Surg. 2016, 152, 783-790. [CrossRef]

14. Lanz, J.; Kim, W.K.; Walther, T.; Burgdorf, C.; Mollmann, H.; Linke, A.; Redwood, S.; Thilo, C.; Hilker, M.; Joner, M.; et al. Safety and efficacy of a self-expanding versus a balloon-expandable bioprosthesis for transcatheter aortic valve replacement in patients with symptomatic severe aortic stenosis: A randomised non-inferiority trial. Lancet 2019, 394, 1619-1628. [CrossRef]

15. Barth, S.; Reents, W.; Zacher, M.; Kerber, S.; Diegeler, A.; Schieffer, B.; Schreiber, M.; Lauer, B.; Kuntze, T.; Dahmer, M.; et al. Multicentre propensity-matched comparison of transcatheter aortic valve implantation using the ACURATE TA/neo self-expanding versus the SAPIEN 3 balloon-expandable prosthesis. EuroIntervention 2019, 15, 884-891. [CrossRef] 
16. Costa, G.; Buccheri, S.; Barbanti, M.; Picci, A.; Todaro, D.; Di Simone, E.; La Spina, K.; D'Arrigo, P.; Criscione, E.; Nastasi, M.; et al. Outcomes of three different new generation transcatheter aortic valve prostheses. Catheter. Cardiovasc. Interv. 2019. [CrossRef]

17. Husser, O.; Kim, W.K.; Pellegrini, C.; Holzamer, A.; Walther, T.; Mayr, P.N.; Joner, M.; Kasel, A.M.; Trenkwalder, T.; Michel, J.; et al. Multicenter Comparison of Novel Self-Expanding Versus Balloon-Expandable Transcatheter Heart Valves. JACC Cardiovasc. Interv. 2017, 10, 2078-2087. [CrossRef]

18. Mauri, V.; Kim, W.K.; Abumayyaleh, M.; Walther, T.; Moellmann, H.; Schaefer, U.; Conradi, L.; Hengstenberg, C.; Hilker, M.; Wahlers, T.; et al. Short-Term Outcome and Hemodynamic Performance of Next-Generation Self-Expanding Versus Balloon-Expandable Transcatheter Aortic Valves in Patients With Small Aortic Annulus: A Multicenter Propensity-Matched Comparison. Circ. Cardiovasc. Interv. 2017, 10. [CrossRef]

19. Schaefer, A.; Linder, M.; Seiffert, M.; Schoen, G.; Deuschl, F.; Schofer, N.; Schneeberger, Y.; Blankenberg, S.; Reichenspurner, H.; Schaefer, U.; et al. Comparison of latest generation transfemoral self-expandable and balloon-expandable transcatheter heart valves. Interact. Cardiovasc. Thorac. Surg. 2017, 25, 905-911. [CrossRef]

20. Moriyama, N.; Vento, A.; Laine, M. Safety of Next-Day Discharge After Transfemoral Transcatheter Aortic Valve Replacement With a Self-Expandable Versus Balloon-Expandable Valve Prosthesis. Circ. Cardiovasc. Interv. 2019, 12, e007756. [CrossRef]

21. Pagnesi, M.; Kim, W.K.; Conradi, L.; Barbanti, M.; Stefanini, G.G.; Zeus, T.; Pilgrim, T.; Schofer, J.; Zweiker, D.; Testa, L.; et al. Transcatheter Aortic Valve Replacement With Next-Generation Self-Expanding Devices: A Multicenter, Retrospective, Propensity-Matched Comparison of Evolut PRO Versus Acurate neo Transcatheter Heart Valves. JACC Cardiovasc. Interv. 2019, 12, 433-443. [CrossRef]

22. Stroup, D.F.; Berlin, J.A.; Morton, S.C.; Olkin, I.; Williamson, G.D.; Rennie, D.; Moher, D.; Becker, B.J.; Sipe, T.A.; Thacker, S.B. Meta-analysis of observational studies in epidemiology: A proposal for reporting. Meta-analysis Of Observational Studies in Epidemiology (MOOSE) group. JAMA 2000, 283, 2008-2012. [CrossRef]

23. Liberati, A.; Altman, D.G.; Tetzlaff, J.; Mulrow, C.; Gotzsche, P.C.; Ioannidis, J.P.; Clarke, M.; Devereaux, P.J.; Kleijnen, J.; Moher, D. The PRISMA statement for reporting systematic reviews and meta-analyses of studies that evaluate health care interventions: Explanation and elaboration. PLoS Med. 2009, 6, e1000100. [CrossRef]

24. Higgins, J.P.; Altman, D.G.; Gotzsche, P.C.; Juni, P.; Moher, D.; Oxman, A.D.; Savovic, J.; Schulz, K.F.; Weeks, L.; Sterne, J.A.; et al. The Cochrane Collaboration's tool for assessing risk of bias in randomised trials. BMJ 2011, 343, d5928. [CrossRef]

25. Sterne, J.A.; Hernan, M.A.; Reeves, B.C.; Savovic, J.; Berkman, N.D.; Viswanathan, M.; Henry, D.; Altman, D.G.; Ansari, M.T.; Boutron, I.; et al. ROBINS-I: A tool for assessing risk of bias in non-randomised studies of interventions. BMJ 2016, 355, i4919. [CrossRef]

26. Kappetein, A.P.; Head, S.J.; Genereux, P.; Piazza, N.; van Mieghem, N.M.; Blackstone, E.H.; Brott, T.G.; Cohen, D.J.; Cutlip, D.E.; van Es, G.A.; et al. Updated standardized endpoint definitions for transcatheter aortic valve implantation: The Valve Academic Research Consortium-2 consensus document. J. Am. Coll. Cardiol. 2012, 60, 1438-1454. [CrossRef]

27. Higgins, J.P.; Thompson, S.G.; Deeks, J.J.; Altman, D.G. Measuring inconsistency in meta-analyses. BMJ 2003, 327, 557-560. [CrossRef]

28. Wan, X.; Wang, W.; Liu, J.; Tong, T. Estimating the sample mean and standard deviation from the sample size, median, range and/or interquartile range. BMC Med. Res. Methodol. 2014, 14, 135. [CrossRef]

29. Sathananthan, J.; Hensey, M.; Fraser, R.; Landes, U.; Blanke, P.; Hatoum, H.; Dasi, L.P.; Sedaghat, A.; Bapat, V.N.; Leipsic, J.; et al. Implications of hydrodynamic testing to guide sizing of self-expanding transcatheter heart valves for valve-in-valve procedures. Catheter. Cardiovasc. Interv. 2019. [CrossRef]

30. Gozdek, M.; Ratajczak, J.; Arndt, A.; Zieliński, K.; Pasierski, M.; Matteucci, M.; Fina, D.; Jiritano, F.; Meani, P.; Raffa, G.M.; et al. Transcatheter aortic valve replacement with Lotus and Sapien 3 prosthetic valves: A systematic review and meta-analysis. J. Thorac. Dis. 2020. (ahead of print).

31. Ando, T.; Briasoulis, A.; Holmes, A.A.; Taub, C.C.; Takagi, H.; Afonso, L. Sapien 3 versus Sapien XT prosthetic valves in transcatheter aortic valve implantation: A meta-analysis. Int. J. Cardiol. 2016, 220, 472-478. [CrossRef] 
32. Kodali, S.; Thourani, V.H.; White, J.; Malaisrie, S.C.; Lim, S.; Greason, K.L.; Williams, M.; Guerrero, M.; Eisenhauer, A.C.; Kapadia, S.; et al. Early clinical and echocardiographic outcomes after SAPIEN 3 transcatheter aortic valve replacement in inoperable, high-risk and intermediate-risk patients with aortic stenosis. Eur. Heart J. 2016, 37, 2252-2262. [CrossRef]

33. Noble, S.; Stortecky, S.; Heg, D.; Tueller, D.; Jeger, R.; Toggweiler, S.; Ferrari, E.; Nietlispach, F.; Taramasso, M.; Maisano, F.; et al. Comparison of procedural and clinical outcomes with Evolut $\mathrm{R}$ versus Medtronic CoreValve: A Swiss TAVI registry analysis. EuroIntervention 2017, 12, e2170-e2176. [CrossRef]

34. Naber, C.K.; Pyxaras, S.A.; Ince, H.; Frambach, P.; Colombo, A.; Butter, C.; Gatto, F.; Hink, U.; Nickenig, G.; Bruschi, G.; et al. A multicentre European registry to evaluate the Direct Flow Medical transcatheter aortic valve system for the treatment of patients with severe aortic stenosis. EuroIntervention 2016, 12, e1413-e1419. [CrossRef]

35. Wendler, O.; Schymik, G.; Treede, H.; Baumgartner, H.; Dumonteil, N.; Ihlberg, L.; Neumann, F.J.; Tarantini, G.; Zamarano, J.L.; Vahanian, A. SOURCE 3 Registry: Design and 30-Day Results of the European Postapproval Registry of the Latest Generation of the SAPIEN 3 Transcatheter Heart Valve. Circulation 2017, 135, 1123-1132. [CrossRef]

36. Thomas, M.; Schymik, G.; Walther, T.; Himbert, D.; Lefevre, T.; Treede, H.; Eggebrecht, H.; Rubino, P.; Michev, I.; Lange, R.; et al. Thirty-day results of the SAPIEN aortic Bioprosthesis European Outcome (SOURCE) Registry: A European registry of transcatheter aortic valve implantation using the Edwards SAPIEN valve. Circulation 2010, 122, 62-69. [CrossRef]

37. Naber, C.K.; Pyxaras, S.A.; Ince, H.; Latib, A.; Frambach, P.; den Heijer, P.; Wagner, D.; Butter, C.; Colombo, A.; Kische, S. Real-world multicentre experience with the Direct Flow Medical repositionable and retrievable transcatheter aortic valve implantation system for the treatment of high-risk patients with severe aortic stenosis. EuroIntervention 2016, 11, e1314-e1320. [CrossRef]

38. Kowalewski, M.; Gozdek, M.; Raffa, G.M.; Slomka, A.; Zielinski, K.; Kubica, J.; Anisimowicz, L.; Kowalewski, J.; Landes, U.; Kornowski, R.; et al. Transcathether aortic valve implantation with the new repositionable self-expandable Medtronic Evolut R vs. CoreValve system: Evidence on the benefit of a meta-analytical approach. J. Cardiovasc. Med. 2019, 20, 226-236. [CrossRef]

39. Tamburino, C.; Capodanno, D.; Ramondo, A.; Petronio, A.S.; Ettori, F.; Santoro, G.; Klugmann, S.; Bedogni, F.; Maisano, F.; Marzocchi, A.; et al. Incidence and predictors of early and late mortality after transcatheter aortic valve implantation in 663 patients with severe aortic stenosis. Circulation 2011, 123, 299-308. [CrossRef]

40. Kodali, S.; Pibarot, P.; Douglas, P.S.; Williams, M.; Xu, K.; Thourani, V.; Rihal, C.S.; Zajarias, A.; Doshi, D.; Davidson, M.; et al. Paravalvular regurgitation after transcatheter aortic valve replacement with the Edwards sapien valve in the PARTNER trial: Characterizing patients and impact on outcomes. Eur. Heart J. 2015, 36, 449-456. [CrossRef]

41. Gilard, M.; Eltchaninoff, H.; Iung, B.; Donzeau-Gouge, P.; Chevreul, K.; Fajadet, J.; Leprince, P.; Leguerrier, A.; Lievre, M.; Prat, A.; et al. Registry of transcatheter aortic-valve implantation in high-risk patients. N. Engl. J. Med. 2012, 366, 1705-1715. [CrossRef]

42. Choudhury, T.; Solomonica, A.; Bagur, R. The ACURATE neo transcatheter aortic valve system. Exp. Rev. Med. Device. 2018, 15, 693-699. [CrossRef]

(C) 2020 by the authors. Licensee MDPI, Basel, Switzerland. This article is an open access article distributed under the terms and conditions of the Creative Commons Attribution (CC BY) license (http://creativecommons.org/licenses/by/4.0/). 